\title{
Thermal and Spectroscopic Studies of Some Prepared Metal Complexes and Investigation of their Potential Anticancer and Antiviral Drug Activity against SARS- CoV-2 by Molecular Docking Simulation
}

\author{
Ashraf A. El-Bindary 1,* ${ }^{10}$, Mohamed G. El-Desouky ${ }^{2}{ }^{(\mathbb{D})}$, Maher A.M. El-Afify ${ }^{2}{ }^{(\mathbb{D})}$ \\ 1 Chemistry Department, Faculty of Science, Damietta University, Damietta 34517, Egypt; abindary@ yahoo.com (A.A.El- \\ B.); \\ 2 Egyptian propylene and polypropylene company, Port Said 42511, Egypt; ch.moh.gamal@gmail.com (M.G.El-D.); \\ maher.elafify@yahoo.com (M.A.M.El-A.); \\ * Correspondence: abindary@yahoo.com;
}

Scopus Author ID 7006833373

Received: 2.03.2021; Revised: 6.04.2021; Accepted: 10.04.2021; Published: 26.04.2021

\begin{abstract}
A scary viral pneumonia (COVID-19) has recently engulfed the globe. The new strain of the virus, named SARS-CoV-2, belongs to the coronavirus family, so research aims to screen multimodal structure-based structure-design of ligands and drugs and then docked to the main viral protease to investigate the active binding sites. A new 3-acetyl-7-hydroxy coumarin (HL) and its $\mathrm{Cu}(\mathrm{II}), \mathrm{Ni}(\mathrm{II})$, $\mathrm{Zn}$ (II), and $\mathrm{Mn}$ (II) complexes have been formed and characterized by elemental analysis, IR, ${ }^{1} \mathrm{H}$ NMR, and UV visible spectra, as well as magnetic and thermal measurements. Molar conductance experiments have shown that all complexes are non-ionic or non-electrolytes. IR spectra show that the ligand (HL) behaves as a bidentate monobasic ligand coordinating via the oxygen atom of the deprotonated phenolic $-\mathrm{OH}$ group and the nitrogen atom of the azo group $(-\mathrm{N}=\mathrm{N}-)$, forming a six-member chelating ring. The molecular and electronic structures of the investigated compounds were also analyzed using quantum chemical calculations. The complexes' thermal decomposition exposed the outer and inner water molecules as well as the end product, which is mainly metal oxide. The thermodynamic parameter ligand (HL) and its metal complexes are calculated using the Coats-Redfern and Horowitz Metzger methods. Using absorption spectra, the ligand (HL) binding behavior of the calf thymus DNA and its metal complexes were studied. A molecular docking simulation computational method is performed to screen the antiviral activity of drugs, natural drug activity, sources, and anti-SARS-CoV-2 genome inhibitory compounds. The primary virus protease collected from a Bank of Protein Data (PDB\# 6YB7) and docked with a sequence of HL and its complexes. On the other hand, the prediction of binding between azo compound with the breast cancer receptor $3 \mathrm{hb} 5$-oxidoreductase and the prostate cancer mutant $2 \mathrm{q} 7 \mathrm{k}$ - hormone was also made. The docking results were promised and indicated that the reported ligand can firmly bind to the SARS-CoV-2, breast, and prostate cancer leads to inhibition of its infectious impact. The cytotoxic activity of ligand (HL) and its metal complexes was tested against human cancer MCF-7 (breast cancer).
\end{abstract}

Keywords: coumarin complexes; molecular docking; COVID-19; SARS-CoV-2; CT-DNA binding, anticancer; cytotoxicity.

(C) 2021 by the authors. This article is an open-access article distributed under the terms and conditions of the Creative Commons Attribution (CC BY) license (https://creativecommons.org/licenses/by/4.0/). 


\section{Introduction}

Recent world history is interrupted by highly pathogenic three coronaviruses that originate from fatal human pneumonia with severe acute respiratory syndrome coronavirus (SARS-CoV), SARS-CoV-2, and Middle-East respiratory syndrome coronavirus (MERSCoV). On January $30^{\text {th }}, 2020$, the World Health Organization (WHO) had reported that the COVID-19 outbreak is an international health issue [1,2]. On March 14, 2020, the disease will infect China, 81,026 individuals, with a 3.9 percent case fatality ratio (3194/81026). Respiratory discomfort, malaise, fever, dry cough, dyspnea, and shortness of breath are typical infection symptoms. In advanced extreme cases, pneumonia may be caused by the virus, kidney insufficiency, extreme acute respiratory disturbance, and even death. SARS-COV-2 is a singlestranded RNA genome virus with a length of $30 \mathrm{~kb}$. The main genome region, called ORF1a/b, is $2 / 3$ of the length and codes for non-structural proteins (nsp). Four basic structural proteins comprising a small envelope $(\mathrm{E})$ protein, a matrix $(\mathrm{M})$ protein, a nucleocapsid $(\mathrm{N})$ protein, and a spike (S) glycoprotein are encoded by the remaining genome [3-5]. 3c-like (3CL) protease, papain-like (PLP) protease, and the S protein mainly target the current coronavirus antiviral regime. There is a risk of associated host cell toxicity as protease inhibitors can function nonspecifically on the host homologous protease and may cause serious side effects[6]. The $S$ protein is highly sensitive to mutations, causing this protein to acquire a particular host cell receptor binding pattern, which helps avoid the protein from targeted therapeutics. Because of this, new methods for curtailing SARS-COV-2 infections are mandatory[7,8]. The SARSCOV-2 N protein binds to the leading RNA and plays a variety of pivotal roles in RNA transcription and replication, making it an attractive pharmacological target. Its primary function is to generate a complex of ribonucleoproteins (RNP), which is important for forming highly organized RNA conformation for the replication and transcription of viral RNA and the regulation of infected cell metabolism. Besides, this protein controls host-pathogen interactions involving actin reorganization, host cell cycle progression, and apoptosis. From an architectural point of view, the protein is composed of three distinct but highly conserved portions: the Cterminal domain (CTD), the N-terminal domain (NTD), and the rich linker of Ser/Arg (SR). CTD acts as a dimerization domain, while NTD and SR are responsible, respectively, for binding to RNA and direct phosphorylation. The crystal structure of the SARS-COV-2 NTD (PDB ID: $6 \mathrm{M} 3 \mathrm{M}$ ) has been found to interact via several primary infectivity mediating residues with the 3 'end of the SARS-COV-2 genome and provide precise electrostatic distribution [911]. Such structural knowledge is important to speed up drug discovery against this attractive drug target to block SARS-COV-2 growth. Besides, during infection, the N protein has high expression, is highly immunogenic, and can induce defensive immune responses targeting SARS-COV-2. Herein, we adopted molecular docking for HL and their complexes with the primary virus protease (6YB7). The results of this research may encourage the development of new antiviral drugs and strategies for vaccination against this high-priority virus [12-14].

On the other hand, the World Health Organization puts the global prevalence of cancer at 18.1 million new cases in 2018 and 9.6 million deaths. Worldwide, one in five men and one in six women are estimated to develop cancer in childhood, while one in eight men and one in eleven women die from the disease. Most new cases worldwide are female lung and breast cancers; the highest annual death rate is attributed to lung cancer (1.8 million deaths, 18.4 percent of total), the poor prognosis for this cancer and colorectal follow-up cancer $(881,000$ deaths, 9.2 percent), stomach cancer $(783,000$ deaths, 8.2 percent $)$, and hepatic cancer $(881,000$ 
deaths, 9.2 percent) $(782,000$ deaths, 8.2 percent). In recent years, azo dyes have attracted wide interest and have found many applications in different fields such as textile fiber dyeing, different material coloring, biological-medical studies, organic synthesis, and advanced applications, including optical storage capacity, optical switching, holography, and non-linear optical properties [15].

In this work, the structural characterization of 3-acetyl-7-hydroxy coumarin (HL) and its metal complexes ( $\mathrm{Cu}(\mathrm{II}), \mathrm{Ni}(\mathrm{II}), \mathrm{Zn}(\mathrm{II})$, and $\mathrm{Mn}$ (II) are discussed. Different spectroscopic techniques have been used. IR spectra indicate that the ligand (HL) acts as a monobasic bidentate ligand that coordinates through the azo group's nitrogen atom $(-\mathrm{N}=\mathrm{N}-)$ and the oxygen atom of the deprotonated phenolic -OH group. Optimized bond lengths, bond angles, and quantum chemical parameters were used to measure the ligand (HL) and its metal complexes. The thermodynamic parameters of the ligand (HL) and its metal complexes are also measured using the Coats Redfern and Horwitz Metzger methods. The absorption spectra analyzed the DNA binding behavior of the calf thymus of HL and its metal complexes. The prediction of binding between azo compound with the SARS-COV-2 receptor 6YB7, the breast cancer receptor $3 \mathrm{hb} 5$-oxidoreductase, and the prostate cancer mutant $2 \mathrm{q} 7 \mathrm{k}$ - hormone was based on molecular docking. Cytotoxic activity against human cancer MCF-7 has been tested by ligand and its metal complexes (breast cancer) [16,17].

\section{Materials and Methods}

\subsection{Chemicals and instruments.}

Here, the chemicals used are of pure grade in this analysis and used without purification Table 1. Sigma-Aldrich Chemical Corporation, USA, purchased DMSO, $\left(\mathrm{CuCl}_{2} .2 \mathrm{H}_{2} \mathrm{O}\right.$, $\mathrm{NiCl}_{2} .6 \mathrm{H}_{2} \mathrm{O}, \mathrm{ZnCl}_{2}$, and $\mathrm{MnCl}_{2} \cdot 4 \mathrm{H}_{2} \mathrm{O}$ ). The devices and related models are described as follows:

Table 1. List of instruments.

\begin{tabular}{l|l} 
Type of analysis & Models \\
\hline Elemental analyses & Automatic Analyzer CHNS Vario ELIII, Germany \\
\hline Conductance & Jenway 4010 conductivity meter \\
\hline FTIR spectra & Jasco FTIR-4100 spectrophotometer \\
\hline${ }^{1}$ HNMR spectra & Varian Mercury VX-300 NMR spectrometer, $300 \mathrm{MHz}$ \\
\hline Electronic spectra & Perkin-Elmer AA800 spectrophotometer \\
\hline Thermogravimetric (TG) & AAS.Shimadzu thermo-gravimetric analyzer TGA-50H \\
\hline Magnetic moment & Johnson Matthey magnetic susceptibility balance
\end{tabular}

\subsection{Synthesis of 3-acetyl-7-hydroxy coumarin $(H L)$.}

The ligand (HL) was prepared by two steps (Figure 1):

Step 1: 3-methoxy carbonyl-7-hydroxy coumarin (0.01 mol) was prepared [18] via the condensation of 2,4-dihydroxy benzaldehyde with dimethyl malonate in the presence of piperidine. The medium temperature should be maintained at $5{ }^{\circ} \mathrm{C}$ by using an ice salt bath during addition, and then the reaction mixture was kept at room temperature overnight and then poured with vigorous stirring into a mixture of crushed ice and water. The solid 3-methoxy carbonyl-7- hydroxy coumarin (Figure 1) was filtered off and washed several times with cold water and recrystallized from ethanol. Elemental analysis: $\mathrm{C}_{11} \mathrm{H}_{8} \mathrm{O}_{4}(\mathrm{M}=204.19) \mathrm{C} 64.4$ (calc. 64.7); H 3.92 (3.96); O 34.38 (31.34) \% IR (KBr): $3430 \mathrm{v}(\mathrm{OH}), 1668 \mathrm{v}(\mathrm{C}=\mathrm{O}) \mathrm{cm}^{-1}$. ${ }^{1} \mathrm{H}$ NMR in DMSO, internal TMS, d (ppm): $\delta 1.5\left(\mathrm{t}, 3 \mathrm{H}, \mathrm{CH}_{3}\right), 4.25\left(\mathrm{q}, 2 \mathrm{H}, \mathrm{CH}_{2}\right), 6.77-7.93(\mathrm{~m}, 7 \mathrm{H}, \mathrm{Ar}-$ $\mathrm{H}), 8.70\left(\mathrm{~s},{ }^{1} \mathrm{H}, \mathrm{OH}\right) \mathrm{ppm}$. 
Step 2: A well-stirred solution of aniline (0.01 mole) in $10 \mathrm{ml}$ ethanol and $5 \mathrm{~mL}$ of 2 $\mathrm{M} \mathrm{HCl}$ was cooled in an ice bath and diazotized with aqueous sodium nitrite solution $(5 \mathrm{ml}$, 0.01 mole). The cooled $\left(0-5{ }^{\circ} \mathrm{C}\right)$ diazonium solution was added drop wisely to a well-stirred solution of (0.01 mol) 3-methoxy carbonyl-7-hydroxy coumarin in (100 mL) ethanol containing solution hydroxide $(0.01 \mathrm{~mol})$ during 45 minutes the mixture was stirred for an additional 30 minutes and then blended. Then it was left in the fridge for 2 hours (Figure 1). It collected the solid commodity, washed it with water, ethanol-dried, and recrystallized [18].

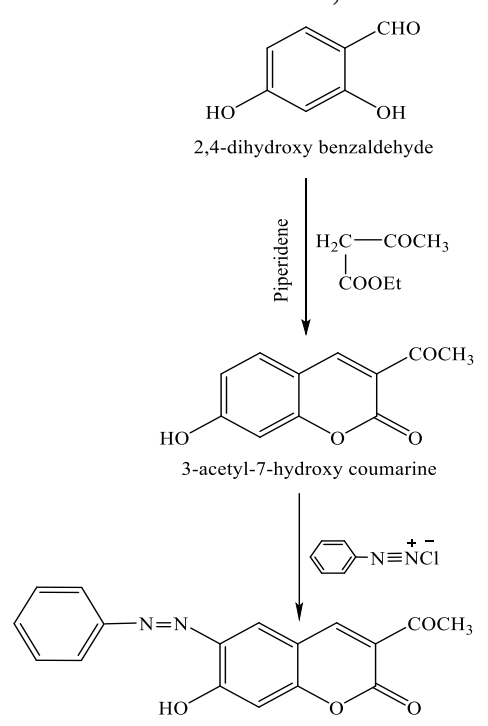

Figure 1. Structure for the preparation acetyl-6-(phenyl azo)-7-hydroxy coumarin (HL).

\subsection{Synthesis of solid complexes.}

All the complexes (1-4) were prepared (Figure 2) by refluxing $1 \mathrm{mmol}$ of the ligand under investigation with $1 \mathrm{mmol}$ of the metal salt $\left(\mathrm{CuCl}_{2} .2 \mathrm{H}_{2} \mathrm{O}, \mathrm{NiCl}_{2} \cdot 6 \mathrm{H}_{2} \mathrm{O}, \mathrm{ZnCl}_{2}\right.$, and $\mathrm{MnCl}_{2} .4 \mathrm{H}_{2} \mathrm{O}$ ) in an ethanolic solution in the water bath for $3 \mathrm{hrs}$. The $\mathrm{pH}$ of the solution was maintained at a value of 5-6 by the addition of dilute ammonia solution (10 wt.\%). The resulting solid complexes were filtered off, washed several times with absolute ethanol, and finally dried in a vacuum desiccator over anhydrous calcium chloride [19].

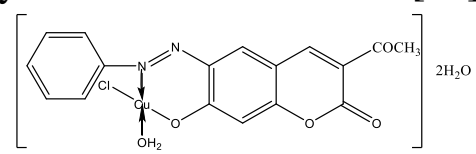<smiles>CC(Cl)(Cl)OC(CCC=O)C(Cl)(Cl)Cl</smiles>

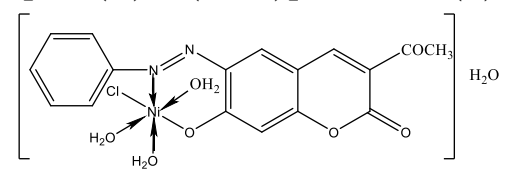

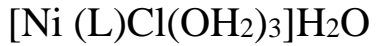

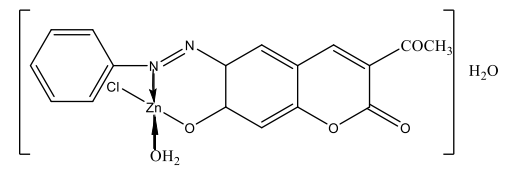

$\left[\mathrm{Zn}(\mathrm{L}) \mathrm{Cl}\left(\mathrm{OH}_{2}\right)\right] \mathrm{H}_{2} \mathrm{O}$

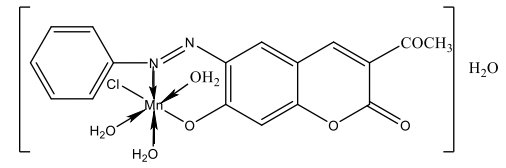

$\left[\mathrm{Mn}(\mathrm{L}) \mathrm{Cl}\left(\mathrm{OH}_{2}\right)_{3}\right] \mathrm{H}_{2} \mathrm{O}$

Figure 2. The proposed structure of the solid complexes (1-4). 


\begin{tabular}{|c|c|c|c|c|c|c|c|c|c|c|}
\hline \multirow{2}{*}{ Compound } & \multirow{2}{*}{ Formula } & \multirow{2}{*}{$\begin{array}{c}\text { Molecular } \\
\text { weight }\end{array}$} & \multirow{2}{*}{ Color } & \multirow{2}{*}{$\begin{array}{l}\text { M.P. } \\
\left({ }^{\circ} \mathrm{C}\right)\end{array}$} & \multirow{2}{*}{$\begin{array}{l}\text { Yield } \\
\%\end{array}$} & \multicolumn{3}{|c|}{ Exp. (Calc.) \% } & \multirow{2}{*}{$\begin{array}{c}\text { Conduct } \Omega^{-1} \\
\mathrm{~cm}^{2} \mathrm{~mol}^{-1}\end{array}$} & \multirow{2}{*}{$\begin{array}{l}\mu \text { eff. } \\
\text { B.M. }\end{array}$} \\
\hline & & & & & & $\mathbf{C}$ & HX. (Calc.) & $\mathbf{N}$ & & \\
\hline $\mathrm{HL}$ & $\mathrm{HL}$ & 308.31 & Brown & 138 & 77 & $66.46(66.22)$ & $3.68(3.93)$ & $9.18(9.09)$ & 14.1 & 1.82 \\
\hline 1 & {$\left[\mathrm{Cu}(\mathrm{L}) \mathrm{Cl}\left(\mathrm{OH}_{2}\right)\right] 2 \mathrm{H}_{2} \mathrm{O}$} & 460.36 & Red & $>300$ & 83 & $44.93(44.35)$ & $3.28(3.73)$ & $6.58(6.09)$ & 12.3 & - \\
\hline 2 & {$\left[\mathrm{Ni}(\mathrm{L}) \mathrm{Cl}\left(\mathrm{OH}_{2}\right)_{3}\right] \mathrm{H}_{2} \mathrm{O}$} & 473.52 & Reddish brown & $>300$ & 86 & $43.07(43.12)$ & $4.12(4.05)$ & $6.42(5.92)$ & 14.7 & 3.3 \\
\hline 3 & $\left.\mathrm{Zn}(\mathrm{L}) \mathrm{Cl}\left(\mathrm{OH}_{2}\right)\right] \mathrm{H}_{2} \mathrm{O}$ & 444.2 & Drak brown & $>300$ & 88 & $46.26(45.96)$ & $3.1(3.41)$ & $6.46(6.31)$ & 13.7 & - \\
\hline 4 & {$\left[\mathrm{Mn}(\mathrm{L}) \mathrm{Cl}\left(\mathrm{OH}_{2}\right)\right] \mathrm{H}_{2} \mathrm{O}$} & 469.77 & Red & $>300$ & 84 & $43.92(43.46)$ & $3.98(4.08)$ & $6.22(5.96)$ & 12.8 & 5.23 \\
\hline
\end{tabular}

Table 3. Assignments of the IR spectral bands of the HL and its complexes.

\begin{tabular}{|c|c|c|c|c|c|c|c|c|c|}
\hline Compound & $v(\mathrm{OH})$ & $v(\mathrm{H} 2 \mathrm{O})$ & $v(A r-H)$ & $v(C=0)$ & $v(C=C)$ & $v(N=N)$ & $v(C-O)$ & $v(M-O)$ & $v(M-N)$ \\
\hline HL & 3444 & - & 3046 & 1666 & 1582 & 1490 & 1240 & - & - \\
\hline 1 & - & 3162 & 3022 & 1660 & 1579 & 1486 & 1205 & 524 & 466 \\
\hline 2 & - & 3150 & 3080 & 1662 & 1578 & 1484 & 1213 & 518 & 442 \\
\hline 3 & - & 3176 & 3040 & 1664 & 1583 & 1481 & 1220 & 507 & 462 \\
\hline 4 & - & 3185 & 3050 & 1662 & 1585 & 1486 & 1214 & 514 & 486 \\
\hline
\end{tabular}


2.4. DNA binding experiments.

Using electronic absorption spectroscopy, the binding properties of the ligand and its complexes to the CT-DNA were analyzed. The stock solution of CT-DNA was prepared in a 5 $\mathrm{mM}$ Tris-HCl/50 mM NaCl buffer ( $\mathrm{pH}=7.2)$, with a ratio of 260 and $280 \mathrm{~nm}$ (A260/A280) UV absorbances of approx. 1.8-1.9, which suggests that the DNA was appropriately protein-free [20], and the concentration was determined by $260 \mathrm{~nm}\left(\mathcal{E}=6600 \mathrm{M}^{-1} \mathrm{~cm}^{-1}\right) \mathrm{UV}$ absorbance [21]. Using $1 \mathrm{~cm}$ quartz cuvettes, electronic absorption spectra $(200-700 \mathrm{~nm})$ were carried out by fixing the ligand or complex $\left(1.00 \times 10^{-3} \mathrm{~mol}^{-1} \mathrm{~L}^{-1}\right)$ concentration, thus progressively increasing the CT-DNA concentration $\left(0.00\right.$ to $1.30 \times 10^{-4}$ mol. $\left.\mathrm{L}^{-1}\right)$. To prevent the absorption of CT-DNA itself, an equivalent quantity of CT-DNA was applied to both the compound solutions and to the reference buffer solution. The intrinsic binding constant $\mathrm{Kb}$ of the CTDNA compound has been determined) [22].

If [DNA] is the concentration of CT-DNA in base pairs, $\epsilon a$ is the coefficient of extension observed at the given DNA concentration for the Ads/[compound], $\epsilon_{f}$ is the coefficient of extension of the free compound in solution, and $\epsilon b$ is the coefficient of extension of the compound when completely bonded to DNA. $\mathrm{K}_{\mathrm{b}}$ is given by the ratio of the slope to the intercept in plots of [DNA]/(ea-ef) vs. [DNA].

\subsection{Cytotoxicity assay.}

The cell line of Mammary gland breast cancer (MCF-7) was obtained from ATCC through Holding Biological Products and Vaccinations Corporation (VACSERA), Cairo, Egypt. The above-mentioned cell line was used to test the inhibitory effects of compounds on the growth of cells using the MTT assay [23].

\section{Results and Discussion}

Effects of the physical properties of the investigated ligand (HL) and its complexes with their elementary analysis, $\mathrm{Mn}(\mathrm{II}), \mathrm{Ni}(\mathrm{II}), \mathrm{Cu}(\mathrm{II})$, and $\mathrm{Zn}(\mathrm{II})$, are collected in Table 2 . The findings of elemental analysis for metal complexes are in good agreement with the measured values that indicate that the complexes have a 1:1:1 ratio (metal: ligand). In most common organic solvents, the ligand and its metal complexes are stable in air and soluble. The molar conductance was measured in DMF at room temperature of the synthesized metal complexes $\left(10^{-3} \mathrm{M}\right)$. The low conductivity values in the $12-15 \Omega^{-1} \mathrm{~cm}^{2} \mathrm{~mol}^{-1}$ range can be due to the presence of chloride ions in the coordination sphere during complex formation rather than ionic interaction with metal ions, and the addition of $\mathrm{AgNO}_{3}$ also forms no white precipitate. This explicitly underpins the fact that all the complexes studied are non-ionic or non-electrolytic [24]. The conductivity values are given in Table 2 for all of the complexes under investigation [25-27].

\subsection{IR spectra.}

The FTIR spectra provide useful information on the existence of the feature group attached to the metal atom by comparing the ligand's IR spectra with its metal complexes Table 3 as follows:

The broad and high strength band due to the $v(\mathrm{OH})$ group that appears at $3444 \mathrm{~cm}^{-1}$ is the product of the free ligand's strong intra- and inter-molecular hydrogen bonding [28]. 
The wideband was due to the $v\left(\mathrm{H}_{2} \mathrm{O}\right)$ vibration in the complexes' spectra in the range $3185-3150 \mathrm{~cm}^{-1}$ and suggested the involvement of water molecules associated with complex formation (coordination and/or water hydration).

Medium bands in the $3080-3022 \mathrm{~cm}^{-1}$ range are induced by the Ar-H stretching vibration in the ligand spectrum and its complexes [28].

In the spectra of its metal complexes, the IR spectrum of the investigated ligand showed the $-\mathrm{C}=\mathrm{C}$-band at $1582 \mathrm{~cm}^{-1}$, appearing almost in the same spot.

In the spectrum of its metal complexes, the band corresponding to $v(C=O)$, which appeared in the ligand spectrum at $1666 \mathrm{~cm}^{-1}$ appeared almost at the same position [18], which can be taken as evidence that $\mathrm{C}=\mathrm{O}$ groups do not participate in the coordination with the metal center.

The band attributable to the $v(\mathrm{~N}=\mathrm{N})$ group that appeared at $1490 \mathrm{~cm}^{-1}$ in the ligand spectrum was moved by $4-9 \mathrm{~cm}^{-1}$ to lower wavenumbers, suggesting their coordination with the metal center [29].

The medium band corresponding to phenolic oxygen to $v(\mathrm{C}-\mathrm{O})$ that appeared at 1240 $\mathrm{cm}^{-1}$ in the ligand spectrum, this band is moved to lower wavenumber upon chelation, the ligand coordinates through its deprotonated form and metal-oxygen bond formation Table 3.

Furthermore, new bands have been found in the $507-524$ and $442-486 \mathrm{~cm}^{-1}$ regions assigned to the formation of $\mathrm{M}-\mathrm{O}$ and $\mathrm{M}-\mathrm{N}$ bonds, respectively. The coordination between the nitrogen atoms of the azo group $(-\mathrm{N}=\mathrm{N}-)$ and the oxygen atoms of the deprotonated phenolic $\mathrm{OH}[30]$ is further confirmed by this.

\subsection{Electronic spectra and magnetic studies.}

The UV-VIS absorption spectra of HL and its metal complexes (1-4) were scanned and assigned to DMF within the 200-900 nm range (DMF does not affect the color). The spectral data is shown in Figure 3. The geometry of the complexes of metals was deduced from the complexes' electronic spectra and magnetic details.

Due to $\pi \rightarrow \pi^{*}$ and $\mathrm{n} \rightarrow \pi^{*}$ transitions, respectively [31], the spectrum of free ligand (HL) shows two intense bands at 342 and $374 \mathrm{~nm}$. Due to the ligand's coordination with metal ions, these transitions are moved to blue or red frequencies. On the continuum of all complexes attributable to LMCT from $\mathrm{N}$ and $\mathrm{O}$ donors, a transition is observed.

Due to the transition $\left({ }^{2} \mathrm{~B}_{1 \mathrm{~g}} \rightarrow{ }^{2} \mathrm{E}_{\mathrm{g}}\right)$ and $\left({ }^{2} \mathrm{~B}_{1 \mathrm{~g}} \rightarrow{ }^{2} \mathrm{~B}_{2 \mathrm{~g}}\right)$ respectively, the electronic absorption spectrum of the $\mathrm{Cu}(\mathrm{II})$ complex includes absorption bands at 446 and $336 \mathrm{~nm}$ to decrease energy. These suggest a planar structure around the copper ion that is square [32].

The $\mathrm{Cu}$ (II) complex magnetic moments in each of its geometry are around 1.85 B.M. This is very similar to the value of just spin, i.e., 1.73 B.M. The values we found in our situation lie at 1.82 B.M. This value is common for the $\mathrm{d}^{9}$-electronic configuration $(\mathrm{s}=1 / 2)$ spin-state mononuclear copper (II) compound. The microanalytical data further supports the monomeric existence of the complex [32].

The magnetic moment of complex Ni (II) is 3.3 B.M. Inside the octahedral High Spin (3.0-3.5 B.M.). The high spin data are derived from the spin-orbit coupling, which is an octahedral structure induces an orbital contribution to the quenched ${ }^{3} \mathrm{~A}_{2 \mathrm{~g}}$ ground state of $\mathrm{Ni}$ (II) ion [33]. Its electronic spectrum displays three $495\left(\mathrm{v}_{3}\right), 456\left(\mathrm{v}_{2}\right)$, and $376 \mathrm{~cm}^{-1}$ ( $\left.\mathrm{v}_{1}\right)$ bands assigned to ${ }^{3} \mathrm{~A}_{2 \mathrm{~g}} \rightarrow{ }^{3} \mathrm{~T}_{1 \mathrm{~g}}(\mathrm{P}),{ }^{3} \mathrm{~A}_{2 \mathrm{~g}} \rightarrow{ }^{3} \mathrm{~T}_{1 \mathrm{~g}}(\mathrm{~F})$ and ${ }^{3} \mathrm{~A}_{2 \mathrm{~g}} \rightarrow{ }^{3} \mathrm{~T}_{1 \mathrm{~g}}(\mathrm{~F})$, respectively, due to the octahedral structure. Apart from these three bands, there are charge-transfer bands has existed at $734 \mathrm{~cm}^{-1}$. 
The diamagnetic $\mathrm{Zn}(\mathrm{II})$ complex electronic absorption spectrum ( $\mathrm{d}^{10}$ configuration) reveals the 438 and $338 \mathrm{~nm}$ bands assigned to intra-ligand charge transfer transitions [33].

The Mn(II) complex's magnetic moment was found to be 5.23 B.M., suggesting the presence in the d-orbital of 5 unpaired electrons and showing a high spin $\mathrm{d}^{5}$ octahedral geometry for $1: 1$ complexes. Due to ${ }^{4} \mathrm{~T}_{1 \mathrm{~g}} \rightarrow{ }^{6} \mathrm{~A}_{1 \mathrm{~g}},{ }^{4} \mathrm{~T}_{2 \mathrm{~g}}(\mathrm{G}) \rightarrow{ }^{6} \mathrm{~A}_{1 \mathrm{~g}}$, and ${ }^{4} \mathrm{~T}_{1 \mathrm{~g}}(\mathrm{D}) \rightarrow{ }^{6} \mathrm{~A}_{1 \mathrm{~g}}$ transition, respectively, the electronic spectrum of the Mn (II) complex displays three bands at 330,402 , and $432 \mathrm{~nm}$ [33].

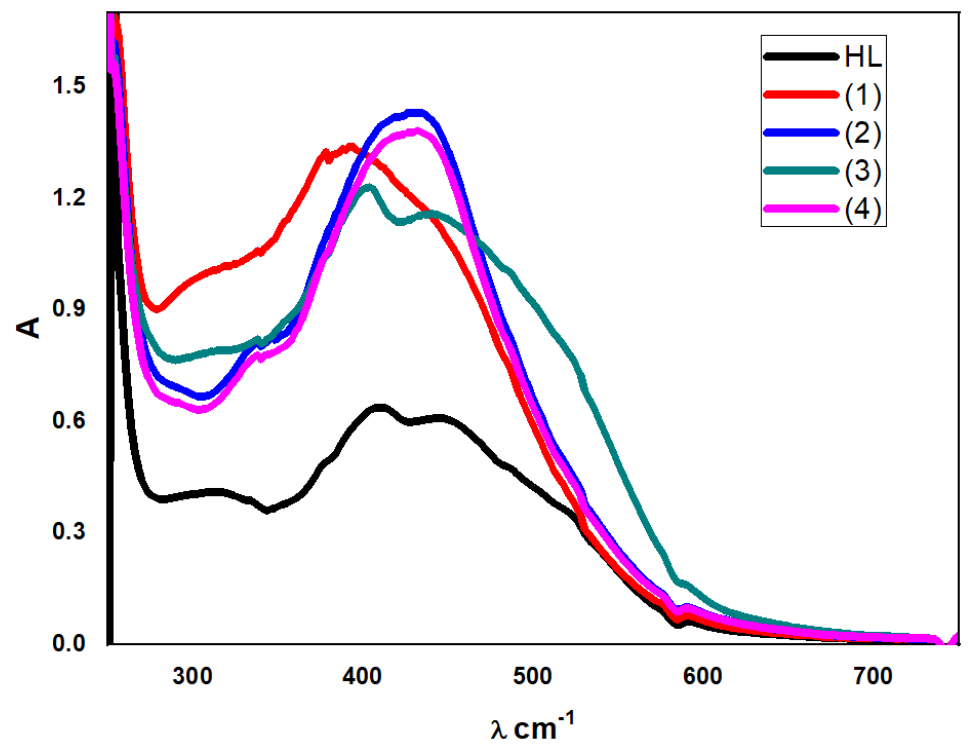

Figure 3. Electronic spectra of the ligand (HL) and its complexes (1-4).

\section{3. ${ }^{1} \mathrm{H}$ and ${ }^{13} \mathrm{C}-\mathrm{NMR}$ spectra.}

\subsection{1. ${ }^{1} \mathrm{H}-\mathrm{NMR}$ spectra.}

Of the investigated ligand HL and their complexes were recorded in DMSO as a solvent.

The chemical shift of the investigated ligand $\mathrm{HL}$ are the following: 2.53 $\left(\mathrm{S}, 3 \mathrm{H}, \mathrm{CoCH}_{3}\right), 7.01,7.82(\mathrm{~m}, 7 \mathrm{H}, \mathrm{Ar}-\mathrm{H}), 8.26(\mathrm{~S}, 1 \mathrm{H}, \mathrm{H}-\mathrm{pyrane}), 8.78(\mathrm{~S}, 1 \mathrm{H}, \mathrm{OH}) \mathrm{ppm}$.

The chemical shift of complexes of the investigated ligand leads to a series of observations. The absence of the signal observed at $8.78 \mathrm{ppm}$ in the free ligands for HL complexes suggests the deprotonation and participation of the $\mathrm{OH}$ group in complexation. The coordinated water molecules were observed at $2.90 \mathrm{ppm}$. There is still some upfield change in all the other signals seen in the free ligand, which may be due to complexity [34].

\subsection{2. ${ }^{13} \mathrm{C}-\mathrm{NMR}$ spectra of the HL Ligand.}

$\delta 194.89(\mathrm{C}=\mathrm{O}$ of Ketone), $\delta 161.3$ (CO of pyrane ring), $\delta 158.54, \delta 151.95, \delta 148.48$, $\delta 137.49, \delta 132.19, \delta 130.25, \delta 129.92, \delta 123.77, \delta 123.30, \delta 121.66, \delta 118.25, \delta 117.34, \delta$ $114.68, \delta 111.80, \delta 104.49, \delta 102.23$ (C-aromatic), $\delta 30.45\left(\mathrm{Co} \mathrm{CH}_{3}\right) \mathrm{ppm}[34]$.

\subsection{Mass spectral studies.}

The examined ligand's mass spectral studies and some of its complexes make to be elucidated by molecular weight. In determining precise molecular weights, obtaining molecular formulas, ionization potential, and the strength of bonds, mass spectroscopy has proved extremely useful [18]. 
3.4.1. Mass spectral of HL.

308( $\left.\mathrm{M}^{+}, 6.23\right), 288(2.49), 267(1.03), 240(1.21), 231(2.94), 213(4.39), 212(7.45)$, 204(2.76), 203(6.17), 197.05(1.94), 189(5.22), 184(1.92), 175(1.71), 169(1.95), 168(1.54), 167(1.66) ,166(2.41), 161(5.37), 156(1.07), 154(1.48), 139(1.14), 138(1.06), 137(1.45), $134(1.01), 133(2.23), 130(1.47), 129(1.80), 128(1.80), 120(1.24), 119(2.05), 118(2.05)$, 117(1.36), 106(1.61), 105(6.98), 104(4.97), 103(1.05), 102(1.06), 941(6.06), 93(76.27), 92(12.44), 91(3.35) , 89(1.41), 88(1.31), 78.07(5.23), 77(31.82), 76(3.39), 66(24.81), 65(15.44), 64(3.3), 63(4.62) , 52(3.48), 51(8.4), 50(30.42), 44(33.28), 43(12.56), 42(5.38), 41(3.22), 40(100) (Figure 4).

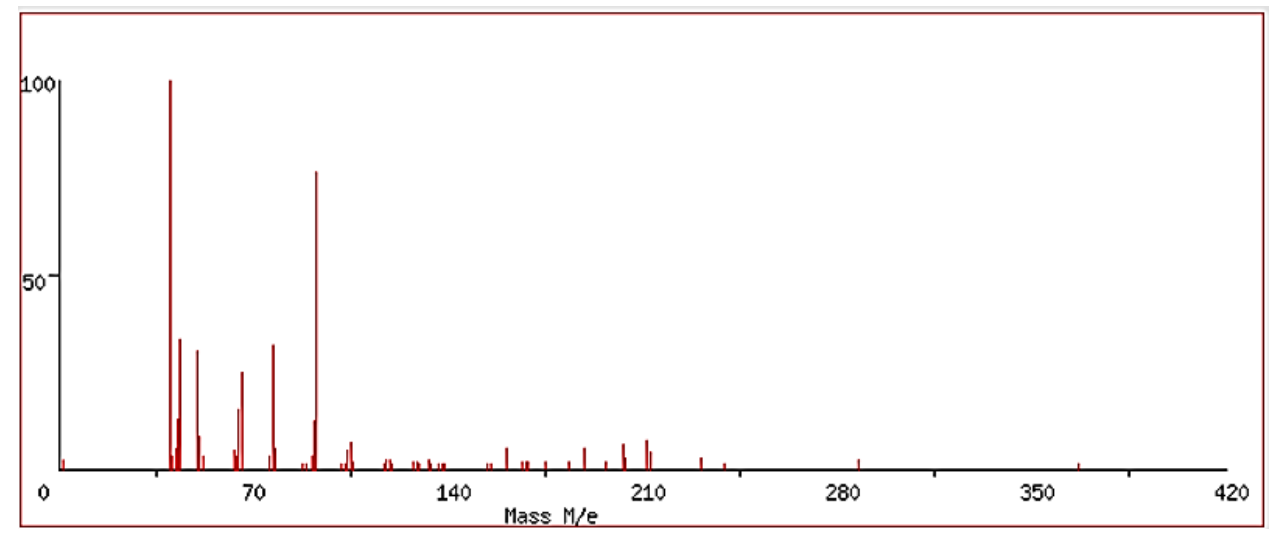

Figure 4. Mass spectrum of HL.

3.4.2. Mass spectral of $\left[\mathrm{Ni}(\mathrm{L}) \mathrm{Cl}\left(\mathrm{OH}_{2}\right)_{3}\right] \mathrm{H}_{2} \mathrm{O}$.

308.02( $\left.\mathrm{M}^{+}, 1.05\right), 267.03(1.42), 203.02(1.04), 195.06(1.40), 190.02(2.42), 186.05(1)$, 169.09(7.59), 168.09(4.41), $167.07(4.87), \quad 166.06(1.44), \quad 159.06(1.04), \quad 135.06(1.39)$, 134.04(1.23), 120.07(1.87), 119.06(6.04), 117.07(1.63), 112.04(1.5), 106.08(1.19), 94.09(8.38), 93.07(100), 92.09(16.14), 91.08(7.63), 79.07(2.44), 78.06(5.87), 76.05(6.21), 74.03(1.06), 73.04(2.10), 68.07(1.13), 67.07(3.83), 66.07(72.52), 65.08(37.92), 64.07(8.58), 63.07(8.63), 61.06(1.12), 54.08(1.21), 53.07(1.97), 52.07(3.22), 51.08(6.22), 50.06(9.68), 46.88(15.45), 43.09(5.27), 41.09(7.04), 40.17(19.51) (Figure 5).

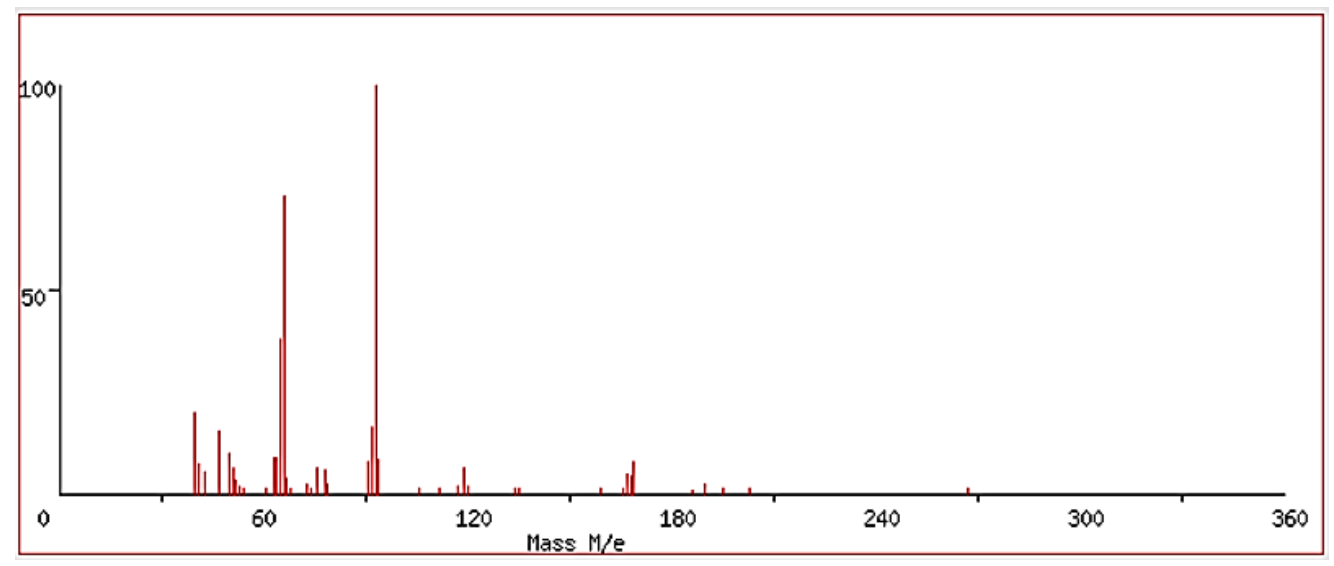

Figure 5. Mass spectrum of $\left[\mathrm{Ni}(\mathrm{L}) \mathrm{Cl}\left(\mathrm{OH}_{2}\right)_{3}\right] \mathrm{H}_{2} \mathrm{O}$.

\subsection{Molecular structure.}

The molecular structure of the ligand (HL) was optimized by the 3-21G base set of the HF process. Using Perkin Elmer ChemBio3D software, the molecule was designed with Perkin 
Elmer ChemBioDraw and optimized [34]. The HL geometric parameters, bond lengths, and bond angles are calculated. The molecular structures calculated for HL are shown in Figure 6.

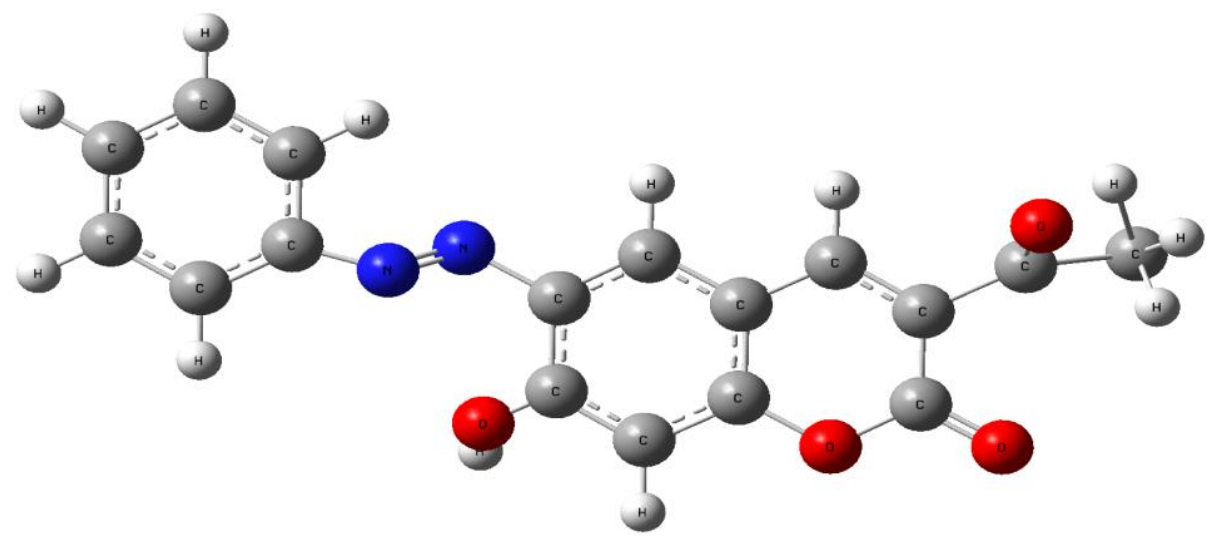

Figure 6. The calculated molecular structure of the investigated ligand (HL).

For HL, molecular structures (HOMO \& LUMO) are listed in Fig. 7 and 8 and $\left[\mathrm{Cu}(\mathrm{L}) \mathrm{Cl}\left(\mathrm{OH}_{2}\right)\right] 2 \mathrm{H}_{2} \mathrm{O},\left[\mathrm{Ni}(\mathrm{L}) \mathrm{Cl}\left(\mathrm{OH}_{2}\right)_{3}\right] \mathrm{H}_{2} \mathrm{O},\left[\mathrm{Zn}(\mathrm{L}) \mathrm{Cl}\left(\mathrm{OH}_{2}\right)\right] \mathrm{H}_{2} \mathrm{O}$ and $\left[\mathrm{Mn}(\mathrm{L}) \mathrm{Cl}\left(\mathrm{OH}_{2}\right)_{3}\right] \mathrm{H}_{2} \mathrm{O}$ for their complexes. To build theoretical models for explaining the structure and conformation barriers in many molecular systems, the HOMO-LUMO energy distance, E, is an important stability index. The smaller the value of $\Delta \mathrm{E}$, the greater the compound's reactivity [35].

In Table 4, the calculated quantum chemical parameters are given. Additional parameters have been measured, such as separation energies, $\Delta \mathrm{E}$, absolute electronegativity, $\chi$, chemical potential $\mathrm{Pi}$, absolute hardness, $\eta$, absolute softness, $\sigma$, global electrophilicity, $\omega$, global softness, $\mathrm{S}$, and additional electronic charge, $\Delta \mathrm{N}_{\text {max }}$.

The value of $\Delta \mathrm{E}$ for ligand $(\mathrm{HL}),\left[\mathrm{Cu}(\mathrm{L}) \mathrm{Cl}\left(\mathrm{OH}_{2}\right)\right] 2 \mathrm{H}_{2} \mathrm{O},\left[\mathrm{Ni}(\mathrm{L}) \mathrm{Cl}\left(\mathrm{OH}_{2}\right)_{3}\right] \mathrm{H}_{2} \mathrm{O}$, $\left[\mathrm{Zn}(\mathrm{L}) \mathrm{Cl}\left(\mathrm{OH}_{2}\right)\right] \mathrm{H}_{2} \mathrm{O}$ and $\left[\mathrm{Mn}(\mathrm{L}) \mathrm{Cl}\left(\mathrm{OH}_{2}\right)_{3}\right] \mathrm{H}_{2} \mathrm{O}$ was found $1.66,3.17,0.60,1.42$ and $0.50 \mathrm{eV}$, respectively [36-38].

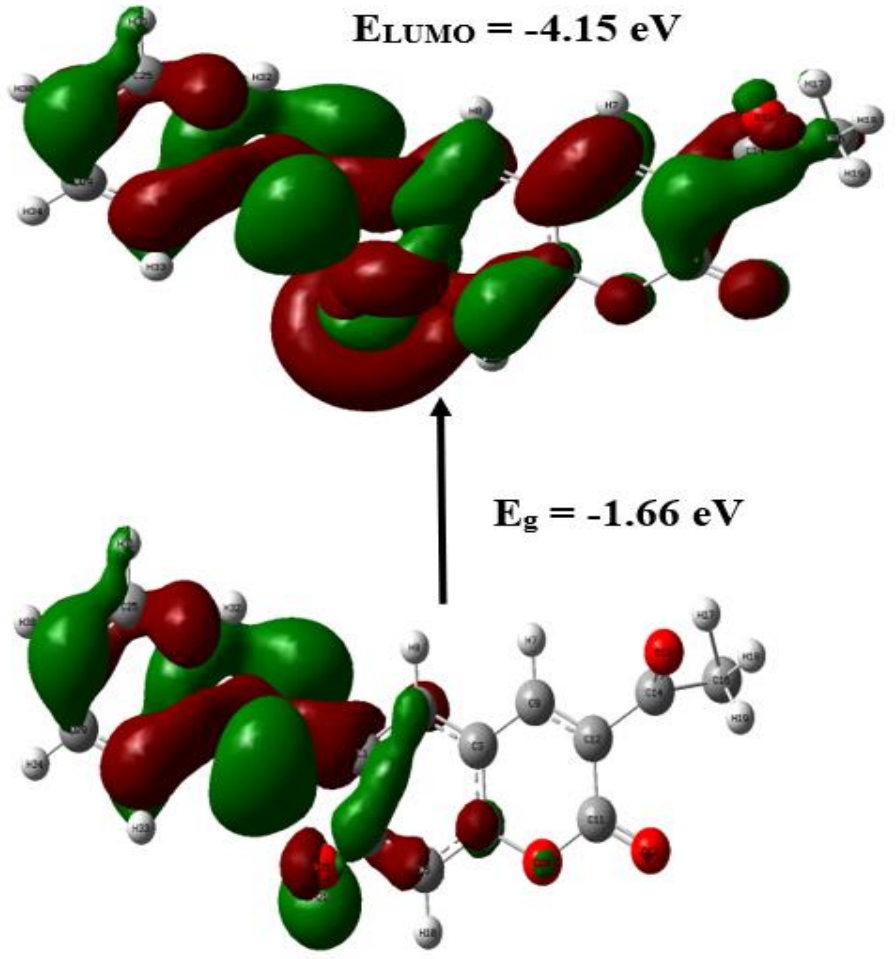

Еномо $=\mathbf{- 5 . 6 1} \mathrm{eV}$

Figure 7. The Highest Occupied Molecular Orbital (HOMO) and the Lowest Unoccupied Molecular Orbital (LUMO) of the investigated ligand (HL) using the B3LYP/LAND level. 


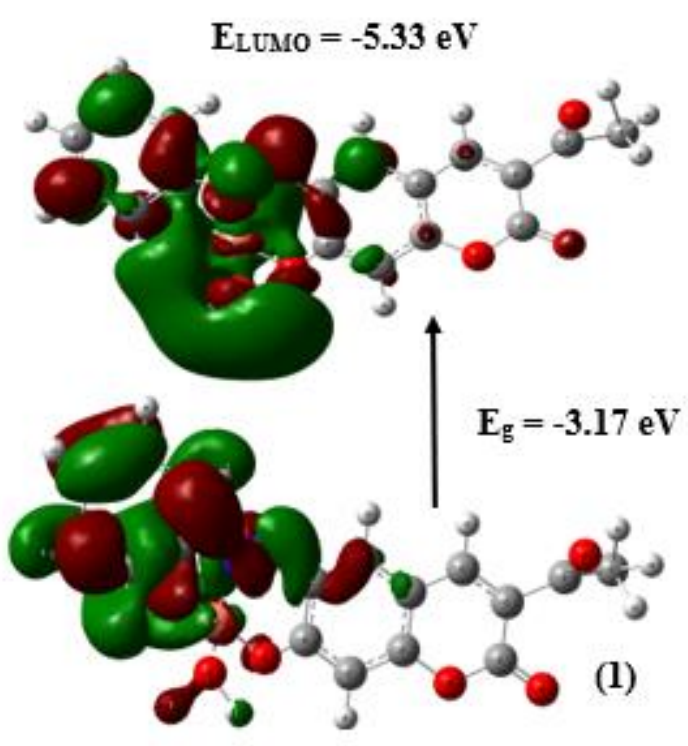

$\mathrm{E}_{\text {Hомо }}=-\mathbf{8 . 5 5} \mathrm{eV}$

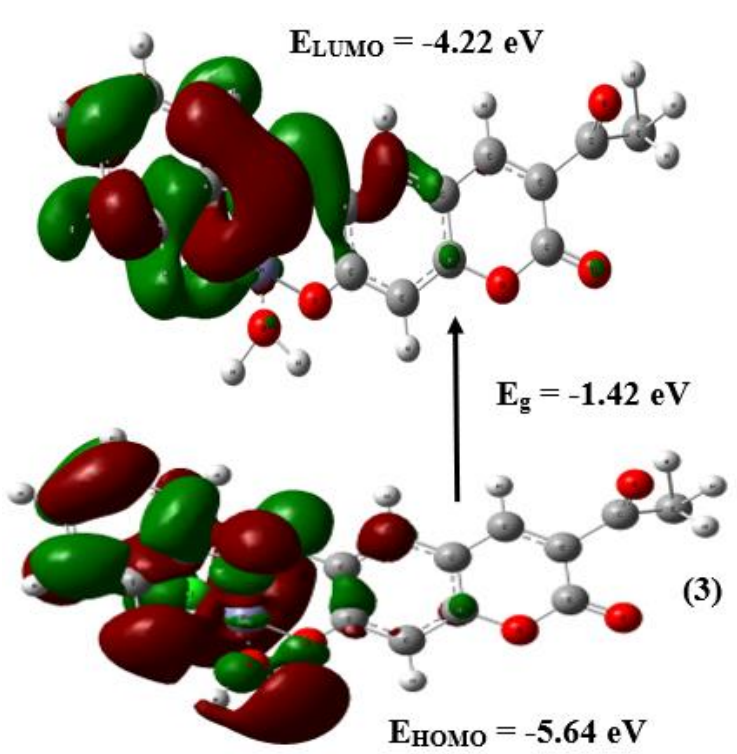

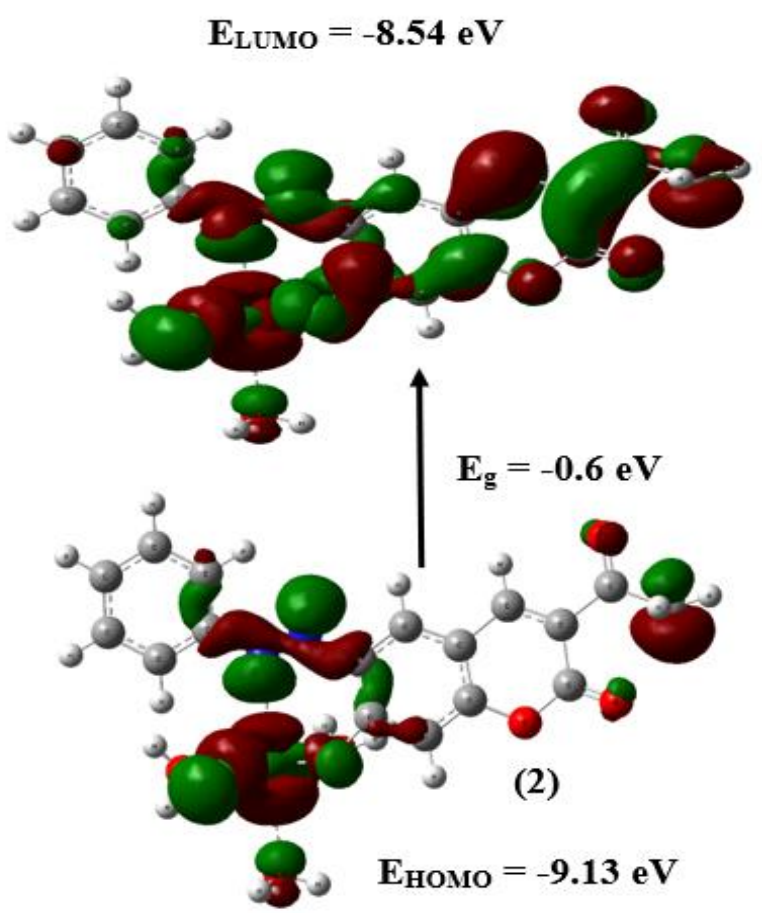

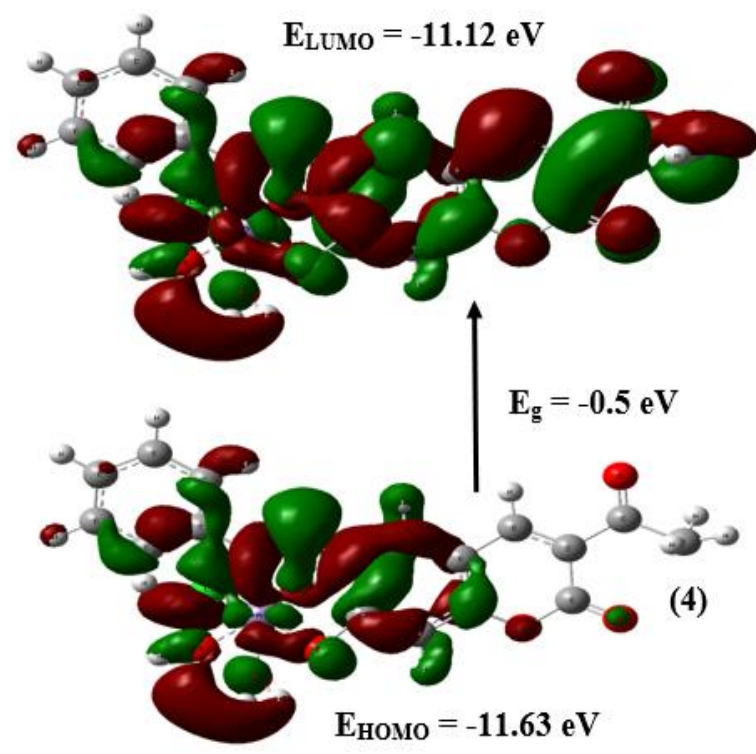

Figure 8. The highest occupied molecular orbital (HOMO) and the lowest unoccupied molecular orbital (LUMO) of the complexes (1-4) using the B3LYP/LAND level.

Table 4. The calculated quantum chemical parameters for the investigated ligand (HL) and its complexes (1-4).

\begin{tabular}{l|l|l|l|l|l|l|l|l|l|l|l} 
Compound & $\begin{array}{l}\text { Eнumo } \\
\mathbf{e V}\end{array}$ & $\begin{array}{l}\mathbf{E}_{\mathbf{L u m o}} \\
\mathbf{e V}\end{array}$ & $\begin{array}{l}\Delta \mathbf{E} \\
\mathbf{e V}\end{array}$ & $\begin{array}{l}\mathbf{X} \\
\mathbf{e V}\end{array}$ & $\begin{array}{l}\mathbf{n} \\
\mathbf{e V}\end{array}$ & $\begin{array}{l}\boldsymbol{\delta} \\
\mathbf{e V}\end{array}$ & $\begin{array}{l}\mathbf{P i} \\
\mathbf{e V}\end{array}$ & $\begin{array}{l}\mathbf{\sigma} \\
\mathbf{e V}^{-1}\end{array}$ & $\begin{array}{l}\mathbf{S} \\
\mathbf{e V}\end{array}$ & $\begin{array}{l}\mathbf{\Omega} \\
\mathbf{e V}\end{array}$ & $\Delta \mathbf{N}_{\max }$ \\
\hline HL & -5.61 & -4.15 & 1.66 & 4.98 & 0.83 & 1.21 & -4.98 & 0.41 & 0.41 & 2.49 & 6.02 \\
\hline$(1)$ & -8.50 & -5.33 & 3.17 & 6.91 & 1.58 & 0.63 & -6.91 & 0.80 & 0.79 & 3.46 & 4.36 \\
\hline$(2)$ & -9.13 & -8.54 & 0.60 & 8.83 & 0.30 & 3.36 & -8.84 & 0.15 & 0.15 & 4.42 & 29.65 \\
\hline$(3)$ & -5.64 & -4.22 & 1.42 & 4.93 & 0.71 & 1.41 & -4.93 & 0.36 & 0.35 & 2.46 & 6.94 \\
\hline$(4)$ & -11.63 & -11.12 & 0.50 & 11.37 & 0.25 & 3.98 & -11.37 & 0.13 & 0.13 & 5.69 & 45.22
\end{tabular}

\subsection{Thermal analysis.}

Based on the thermogravimetric analysis, the ligand (HL) thermal properties and its complexes have been characterized. Table 5 lists the temperature intervals and the percentage 
of mass loss of the ligand. It is clear that the thermal properties of the ligand are influenced by the modification of the substituent.

$\mathrm{HL}$ indicates three phases of decomposition; the first stage is the loss of $\mathrm{C}_{9} \mathrm{H}_{6} \mathrm{~N}_{2} \mathrm{O}$ in the temperature range $45.82-460.5{ }^{\circ} \mathrm{C}$ (Found 53.29 percent and calc. 51.29 percent). The second stage corresponds to the loss of part of the ligand $\left(\mathrm{C}_{7} \mathrm{H}_{3} \mathrm{O}_{2}\right)$ in the temperature range of $460.5-750{ }^{\circ} \mathrm{C}$ (Found 39.33 percent and calc. 39.9 percent). More than $750{ }^{\circ} \mathrm{C}$ is due to the loss of $\mathrm{CH}_{3} \mathrm{O}$ at a temperature in the third stage (Found 7.38 percent and calc. 10.05 percent) [34].

Three decomposition steps were shown by $\left[\mathrm{Cu}(\mathrm{L}) \mathrm{Cl}\left(\mathrm{OH}_{2}\right)\right] 2 \mathrm{H}_{2} \mathrm{O}$. The loss of $\left(\mathrm{C}_{6} \mathrm{H}_{2}+3 \mathrm{H}_{2} \mathrm{O}\right)$ is due to the first stage in the $48-385^{\circ} \mathrm{C}$ temperature range (Found 26.33 percent and calc.27.8). The second stage in the $386-671{ }^{\circ} \mathrm{C}$ temperature range is due to $\left(\mathrm{C}_{11} \mathrm{H}_{9} \mathrm{O}_{3} \mathrm{~N}_{2} \mathrm{Cl}\right)$ failure (Found 58.29 percent and calc. 57.88). At a temperature of more than $671^{\circ} \mathrm{C}$, the third stage leads to loss of $(\mathrm{CuO})$ (Found 15.39 percent and calc. 17.28 percent) [35].

Three decomposition stages were shown by $\left[\mathrm{Ni}(\mathrm{L}) \mathrm{Cl}\left(\mathrm{OH}_{2}\right)_{3}\right] \mathrm{H}_{2} \mathrm{O}$. In the $46-147{ }^{\circ} \mathrm{C}$ temperature range corresponding to the loss of $\left(\mathrm{H}_{2} \mathrm{O}+\mathrm{CH}_{3} \mathrm{O}\right)$, the first stage occurs (Found 9.57 and calc. 10.34). The second stage in the $147-387{ }^{\circ} \mathrm{C}$ temperature range reflected the loss of $\left(3 \mathrm{H}_{2} \mathrm{O}+\mathrm{C}_{2}{ }_{2} \mathrm{H}_{7} \mathrm{~N}_{2} \mathrm{ClO}\right)$ (Found 60.07 and calc.60.08). The third and final stage at temperatures above $387^{\circ} \mathrm{C}$ is due to $\left(\mathrm{C}_{4} \mathrm{OH}+\mathrm{NiO}\right)$ failure (Found 30.35 percent and calc. 29.5 percent) [34].

There are four stages of $\left[\mathrm{Zn}(\mathrm{L}) \mathrm{Cl}\left(\mathrm{OH}_{2}\right)\right] \mathrm{H}_{2} \mathrm{O}$ decomposition. In the $47-297{ }^{\circ} \mathrm{C}$ temperature range, the first stage reflects the loss of $\left(2 \mathrm{H}_{2} \mathrm{O}+\mathrm{CH}_{3} \mathrm{O}\right)$ (Found 15.7 and calc. 15.09). In the $298-439{ }^{\circ} \mathrm{C}$ temperature range, the second stage corresponds to the loss of $\left(\mathrm{C}_{6} \mathrm{H}_{5} \mathrm{NCl}\right)$ (Found 28.4 percent and calc. 28.47 percent). The third stage of the $439-617{ }^{\circ} \mathrm{C}$ temperature range is due to the loss of $\mathrm{C}_{10} \mathrm{H}_{3} \mathrm{NO}_{2}$ (Found 38.04 percent and calc.38.06 percent The fourth stage in the temperature of more than $617^{\circ} \mathrm{C}$ is attributed to the loss of $(\mathrm{ZnO})$ (Found $17.86 \%$ and calc. $18.33 \%)$ [18].

$\left[\mathrm{Mn}\left(\mathrm{L}_{2}\right) \mathrm{Cl}\left(\mathrm{OH}_{2}\right)_{3}\right] \mathrm{H}_{2} \mathrm{O}$ demonstrated four stages of decomposition. The loss of $\left(4 \mathrm{H}_{2} \mathrm{O}+\mathrm{C}_{6} \mathrm{H}_{5} \mathrm{~N}\right)$ is due to the first stage in the $46-378{ }^{\circ} \mathrm{C}$ temperature range (Found 34.7 percent and calc. 33.56 percent). The second stage in the $379-602{ }^{\circ} \mathrm{C}$ temperature range corresponds to $\left(\mathrm{C}_{11} \mathrm{H}_{6} \mathrm{NO}_{3} \mathrm{Cl}\right)$ loss (Found 53.58 percent and calc. 50.12 percent). At temperatures above 602 ${ }^{\circ} \mathrm{C}$, the last and third states represented a loss of $(\mathrm{MnO})$ (Found 11.69 percent and calc. 15.1 percent) [18].

Table 5. Thermal analysis data for the ligand HL and its complexes.

\begin{tabular}{|c|c|c|c|}
\hline Complexes & Temp. range $\circ \mathrm{C}$ & $\begin{array}{c}\text { Found mass loss } \\
\text { (calc.) } \%\end{array}$ & Assignment \\
\hline \multirow[t]{3}{*}{$\mathrm{HL}$} & $45.82-460.5$ & $53.29(51.29)$ & Loss of $\mathrm{C}_{9} \mathrm{H}_{6} \mathrm{~N}_{2} \mathrm{O}$ \\
\hline & $460.5-750$ & $39.33(39.9)$ & Loss of $\mathrm{C}_{7} \mathrm{H}_{3} \mathrm{O}_{2}$ \\
\hline & $>750$ & $7.38(10.05)$ & Loss of $\mathrm{CH}_{3} \mathrm{O}$ \\
\hline \multirow[t]{3}{*}[\mathrm{Cu}(\mathrm{L})\mathrm{Cl}(\mathrm{OH}_{2})]{$2 \mathrm{H}_{2} \mathrm{O}$} & $48-385$ & $26.33(27.8)$ & Loss of $\mathrm{C}_{6} \mathrm{H}_{2}+3 \mathrm{H}_{2} \mathrm{O}$ \\
\hline & $386-671$ & $58.29(57.88)$ & Loss of $\mathrm{C}_{11} \mathrm{H}_{9} \mathrm{O}_{3} \mathrm{~N}_{2} \mathrm{Cl}$ \\
\hline & $>672$ & $15.39(17.28)$ & Loss of $\mathrm{CuO}$ \\
\hline \multirow[t]{3}{*}[\mathrm{Ni}(\mathrm{L})\mathrm{Cl}(\mathrm{OH}_{2})_{3}]{$\mathrm{H}_{2} \mathrm{O}$} & $46-147$ & $9.57(10.34)$ & Loss of $\mathrm{H}_{2} \mathrm{O}+\mathrm{CH}_{3} \mathrm{O}$ \\
\hline & $147-387$ & $60.07(60.08)$ & Loss of $3 \mathrm{H}_{2} \mathrm{O}+\mathrm{C}_{12} \mathrm{H}_{7} \mathrm{~N}_{2} \mathrm{ClO}$ \\
\hline & $>387$ & $30.35(29.5)$ & Loss of $\mathrm{C}_{4} \mathrm{OH}+\mathrm{NiO}$ \\
\hline \multirow[t]{4}{*}[\mathrm{Zn}(\mathrm{L})\mathrm{Cl}(\mathrm{OH}_{2})]{$\mathrm{H}_{2} \mathrm{O}$} & $47-297$ & $15.7(15.09)$ & Loss of $2 \mathrm{H}_{2} \mathrm{O}+\mathrm{CH}_{3} \mathrm{O}$ \\
\hline & $298-439$ & $28.4(28.47)$ & Loss of $\mathrm{C}_{6} \mathrm{H}_{5} \mathrm{NCl}$ \\
\hline & $439-617$ & $38.04(38.06)$ & Loss of $\mathrm{C}_{10} \mathrm{H}_{3} \mathrm{NO}_{2}$ \\
\hline & $>617$ & $17.86(18.33)$ & Loss of $\mathrm{ZnO}$ \\
\hline \multirow[t]{3}{*}[\mathrm{Mn}(\mathrm{L})\mathrm{Cl}(\mathrm{OH}_{2})_{3}]{$\mathrm{H}_{2} \mathrm{O}$} & $46-378$ & $34.7(33.56)$ & Loss of $4 \mathrm{H}_{2} \mathrm{O}+\mathrm{C}_{6} \mathrm{H}_{5} \mathrm{~N}$ \\
\hline & $379-602$ & $53.58(50.12)$ & Loss of $\mathrm{C}_{11} \mathrm{H}_{6} \mathrm{NO}_{3} \mathrm{Cl}$ \\
\hline & $>602$ & $11.69(15.1)$ & Loss of $\mathrm{MnO}$ \\
\hline
\end{tabular}


3.7. Calculation of activation thermodynamic parameter.

Using the Coast-Redfern [39] and Horowitz-Metzger [40] methods, the thermodynamic activation parameters of the decomposition processes of the ligand (HL) and its $\mathrm{Cu}$ (II), $\mathrm{Ni}(\mathrm{II})$, $\mathrm{Zn}(\mathrm{II})$ and $\mathrm{Mn}(\mathrm{II})$ complexes, namely activation energy (Ea), enthalpy $\left(\Delta \mathrm{H}^{*}\right)$, entropy $\left(\Delta \mathrm{S}^{*}\right)$, and Gibbs free energy decomposition shift $\left(\Delta \mathrm{G}^{*}\right)$ were graphically assessed.

\subsubsection{Coast-Redfern equation.}

A plot of $\left(\ln \left(-\ln (1-\alpha) \mathrm{T}^{2}\right)\right.$ vs $1 / \mathrm{T}$ was drawn (Figure 9). In Table 6 the $\mathrm{E}_{\mathrm{a}}$ is the energy of activation in $\mathrm{J} \mathrm{mol}^{-1}$ and calculated from the slope and $\mathrm{A}$ in $\left(\mathrm{s}^{-1}\right)$ from the intercept value. The entropy of activation $\left(\Delta S^{*}\right)$ in $\left(\mathrm{J} \cdot \mathrm{mol}^{-1} \cdot \mathrm{K}^{-1}\right)$ calculated [39].
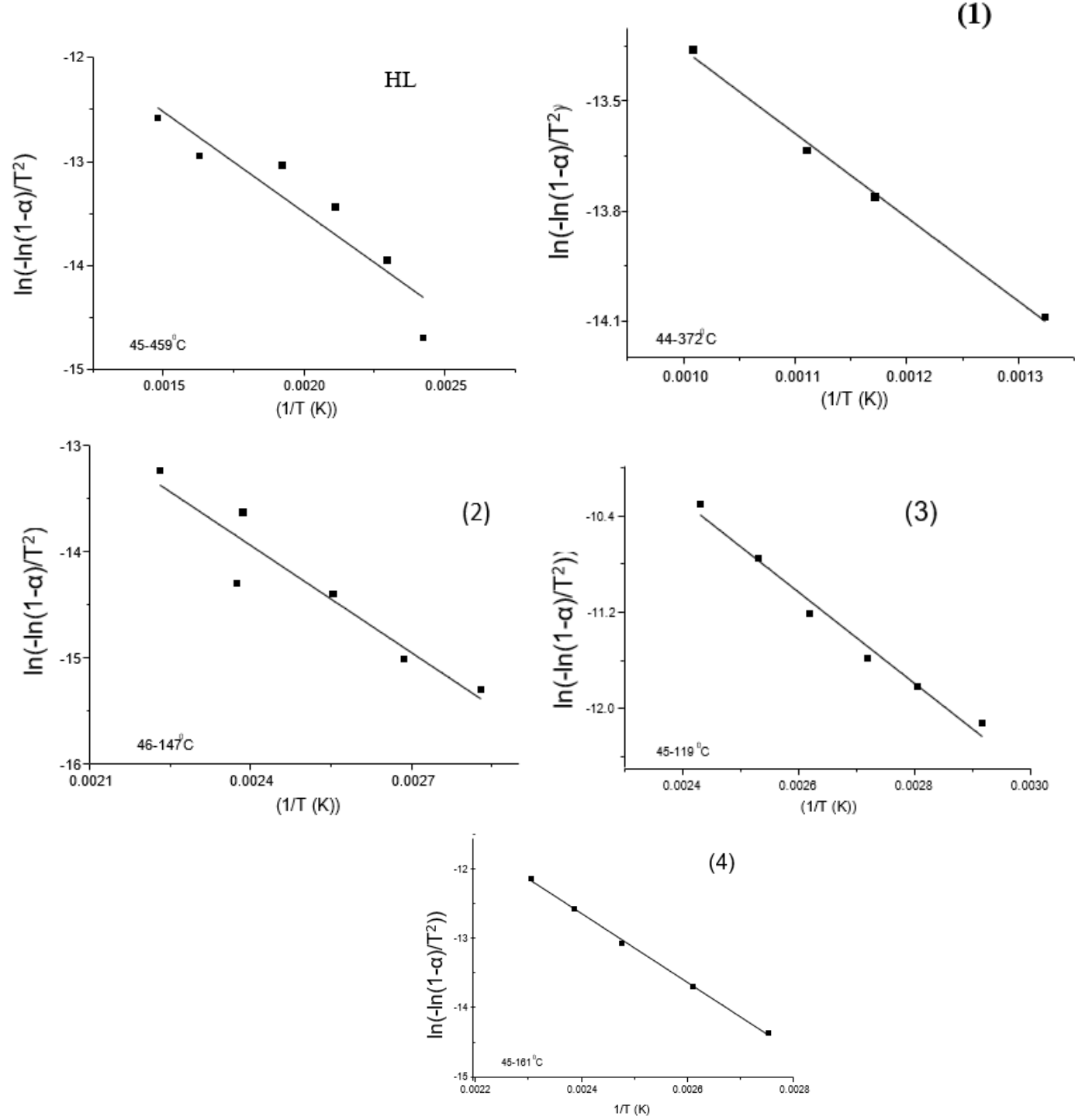

Figure 9. Coats-Redfern (CR) of the ligand (HL) and its complexes (1-4).

\subsubsection{Horowitz- Metzger equation.}

The plot of $\log \left[\log \left(w_{\alpha} / w_{\gamma}\right)\right] v s . \theta$ was drawn and found to be linear (Figure 10), from the slope of which Ea was calculated in Table 6. The calculated values of $\mathrm{Ea}, \mathrm{A}, \Delta S^{*}, \Delta H^{*}$ and $\Delta G^{*}$ for the decomposition steps for the ligand (HL) and its $\mathrm{Cu}(\mathrm{II}), \mathrm{Ni}(\mathrm{II}), \mathrm{Zn}$ (II), and $\mathrm{Mn}$ (II) complexes are summarized in Table 7. [40] 

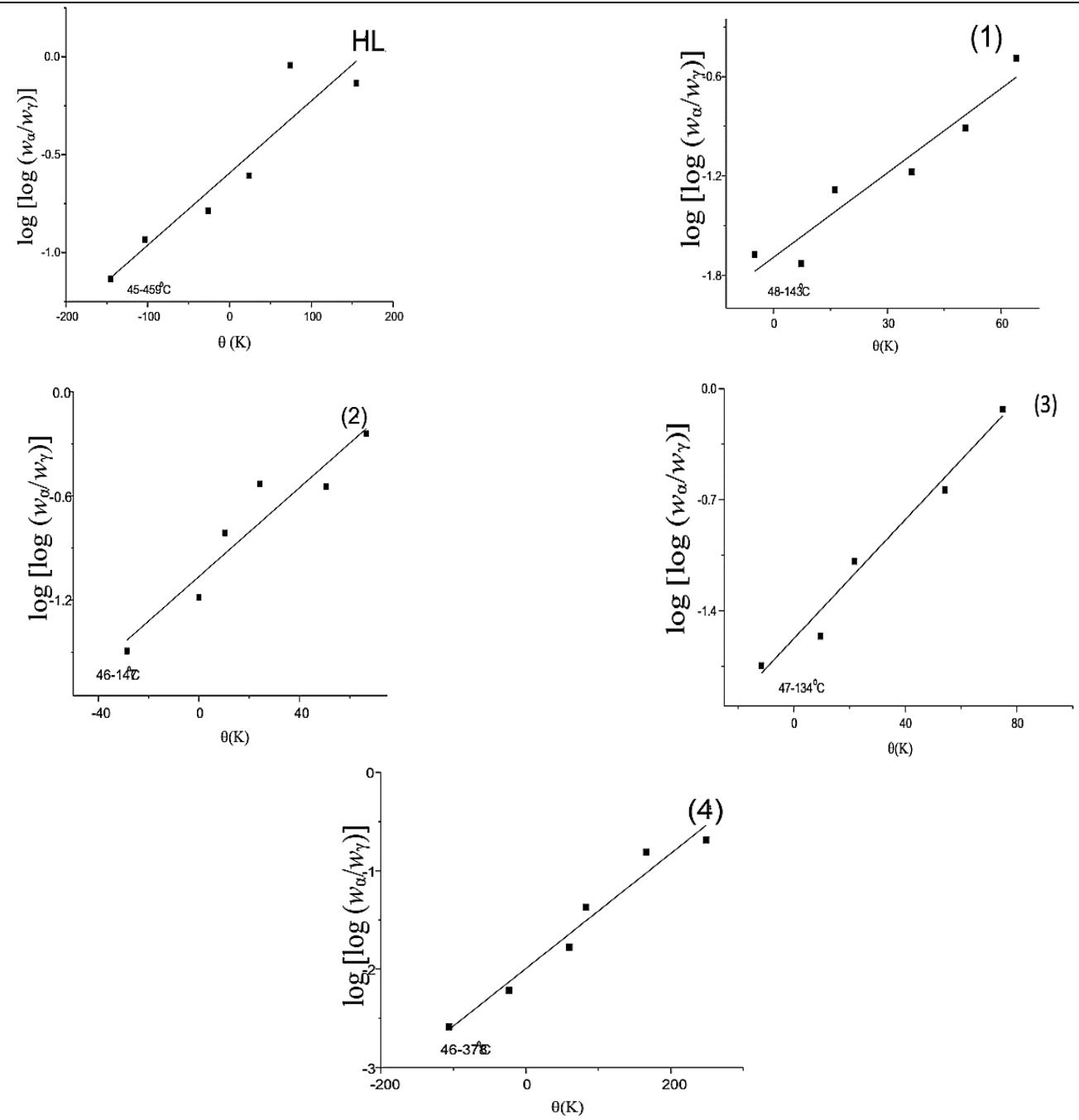

Figure 10. Horowitz-Metzger (HM) of the ligand (HL) and its complexes (1-4).

Table 6. Kinetic parameter of the ligand (HL) and its complexes (1-4).

\begin{tabular}{|c|c|c|c|c|c|c|c|c|}
\hline \multirow[b]{3}{*}{ Compound } & \multirow{3}{*}{$\begin{array}{c}\text { Decomposition } \\
\text { Temperature }\left({ }^{\circ} \mathrm{C}\right)\end{array}$} & \multirow[b]{3}{*}{ Method } & \multirow[b]{3}{*}{ Ea $\left(\mathbf{k J m o l} \mathbf{l}^{-1}\right)$} & \multirow{2}{*}{\multicolumn{4}{|c|}{ Parameter }} & \multirow{3}{*}{$\begin{array}{c}\text { Correlation } \\
\text { coefficient } \\
\text { (R) }\end{array}$} \\
\hline & & & & & & & & \\
\hline & & & & $A\left(S^{-1}\right)$ & $\begin{array}{c}-\Delta S \\
\left(\mathbf{J m o l}^{-1} \mathbf{K}^{-1}\right)\end{array}$ & $\Delta \mathbf{H}^{*}\left(\mathrm{KJmol}^{-1}\right)$ & $\begin{array}{c}\Delta \mathbf{G}^{*} \\
\left(\mathrm{KJmol}^{-1}\right)\end{array}$ & \\
\hline \multirow{2}{*}{ HL } & \multirow{2}{*}{$45-459$} & $\mathrm{CR}$ & 16.2 & 44.5 & $2.76 \times 10^{2}$ & $1.18 \times 10^{4}$ & $1.57 \times 10^{5}$ & 0.848 \\
\hline & & $\mathrm{HM}$ & 19.4 & 30.8 & $2.61 \times 10^{2}$ & $1.51 \times 10^{4}$ & $1.52 \times 10^{5}$ & 0.856 \\
\hline \multirow{2}{*}{1} & \multirow{2}{*}{$45-460$} & $\mathrm{CR}$ & 74.9 & $1.23 \times 10^{3}$ & $1.18 \times 10^{4}$ & $4.42 \times 10^{3}$ & $8.77 \times 10^{3}$ & 0.959 \\
\hline & & HM & 44.3 & $3.18 \times 10^{4}$ & $1.63 \times 10^{2}$ & $4.13 \times 10^{4}$ & $1.01 \times 10^{5}$ & 0.904 \\
\hline \multirow{2}{*}{2} & \multirow{2}{*}{$45-461$} & $\mathrm{CR}$ & 27.9 & $3.12 \times 10^{5}$ & $2.37 \times 10^{2}$ & $2.48 \times 10^{4}$ & $1.13 \times 10^{5}$ & 0.876 \\
\hline & & HM & 33.5 & $5.26 \times 10^{2}$ & $1.95 \times 10^{2}$ & $3.04 \times 10^{4}$ & $1.02 \times 10^{5}$ & 0.885 \\
\hline \multirow{2}{*}{3} & \multirow{2}{*}{$45-462$} & $\mathrm{CR}$ & 38.7 & $6.36 \times 10^{4}$ & $1.55 \times 10^{2}$ & $3.57 \times 10^{4}$ & $9.19 \times 10^{4}$ & 0.874 \\
\hline & & $\mathrm{HM}$ & 47.5 & $7.19 \times 10^{4}$ & $1.54 \times 10^{2}$ & $4.45 \times 10^{4}$ & $1.00 \times 10^{5}$ & 0.965 \\
\hline \multirow{2}{*}{4} & \multirow{2}{*}{$45-463$} & $\mathrm{CR}$ & 24.5 & $1.91 \times 10^{7}$ & $1.10 \times 10^{2}$ & $2.03 \times 10^{4}$ & $7.62 \times 10^{4}$ & 0.871 \\
\hline & & HM & 28.9 & $3.17 \times 10^{2}$ & $2.47 \times 10^{2}$ & $2.47 \times 10^{4}$ & $1.47 \times 10^{5}$ & 0.952 \\
\hline
\end{tabular}

3.8. Molecular docking.

\subsubsection{Anticancer activity.}

In this analysis, the main protease of prostate cancer was retrieved from the database of proteins $(2 q 7 k)$, while breast cancer was retrieved from the database of proteins (3hb5).

The most widely used method of measuring the binding affinity of a ligand is binding energies [5]. Thus, reducing binding energy due to mutation will increase the azo ligand's binding affinity to the receptor [4]. The characteristic feature of the azo coumarin ligand is the presence of various open Active Hydrogen Bonding Sites. This function gives them the ability 
to be strong protein binding inhibitors and helps to generate increased inhibitory compounds. Results confirm that an efficient inhibitor of prostate cancer mutant $2 \mathrm{q} 7 \mathrm{k}$ - hormone and $3 \mathrm{hb} 5$ oxidoreductase breast cancer is the azo dye ligand derived from 3-acetyl-7-hydroxy coumarin (Table 7, Figures 11 and 12).

Table 7. Docking interaction with 2q7k and $3 \mathrm{hb} 5$.

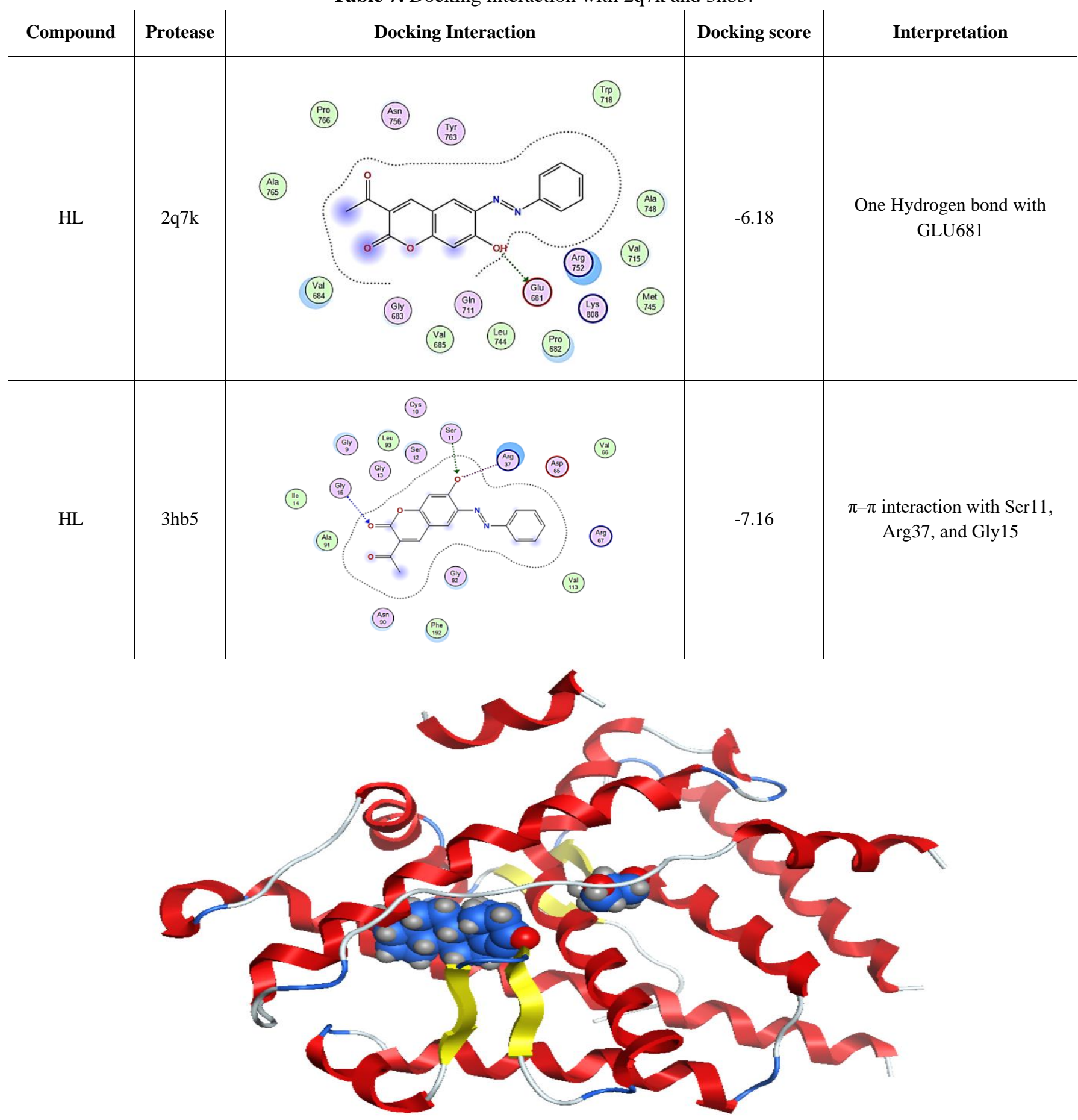

Figure 11. 3D interaction between HL and 2q7k. 


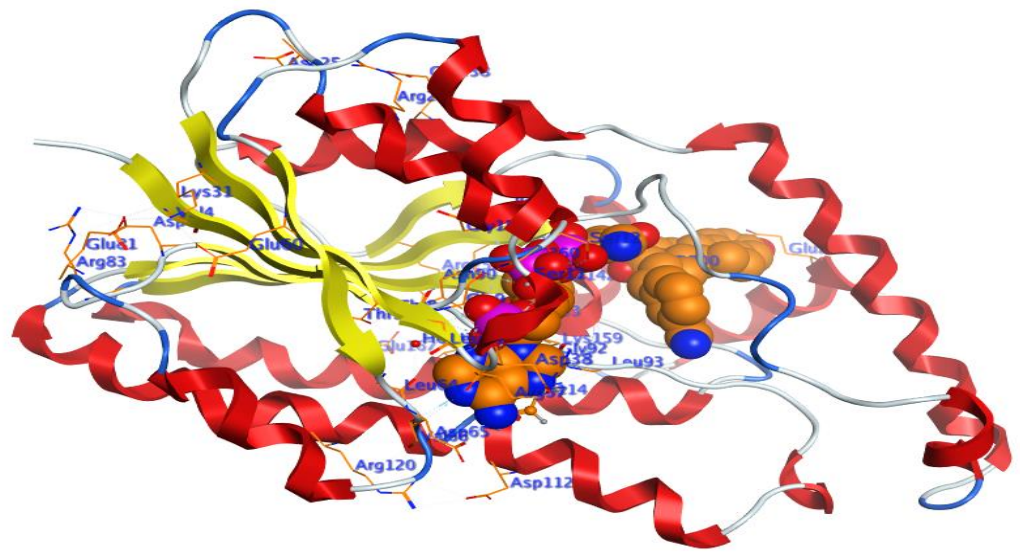

Figure 12. 3D interaction between HL and 3hb5.

\subsubsection{Anticovid-19.}

In this analysis, the main protease of SARS-CoV-2 was retrieved from the database of proteins (PDB ID: 6YB7, chain A) [41]. After validation of the model, protein sequence coordination and subsequent molecular docking was performed to assess the previously recorded medicines' antiviral activity and natural sources of SARS-CoV-2 protease. In each case, the energy and inhibition constants are reported. In their active physiological environments, all the compounds were optimized. The ligands against SARS-CoV-2 protease were checked before it was ensured that the tested drugs and ligands' configurations were in the optimized active arrangement. Finally, based on the study of the expected binding modes and their scores, the ligands were selected $[42,43]$.

Compounds with lower docking molecular scores would have higher levels of binding correspondence to the $6 \mathrm{YB} 7$ protein aim. A ligand's orientation is measured with a shape scoring feature that approximates the ligand-binding receptor's energies. The function of shape scoring is an analytical function similar to van der Waals' enticing power. After the initial orientation and scoring reviews, energy minimization is carried out to determine the nearest energy assessment within the receptor-binding sites, minimization points. Since then, the complex formed between the ligands screened with higher binding energies, the main protease of SARS-CoV-2, is highly stable. The development of excessive hydrogen bonding with the key protease chain reveals the ligand's ability to lock the receptor binds to the virus $[44,45]$.

As shown in Table 8 docking score was -5.168 , and the binding between HL and 6YB7 by $\pi-\pi$ interaction with Val 18 , Lys 97 , and Ser 121 Figure 13.

Table 8. Docking interaction with 6YB7.

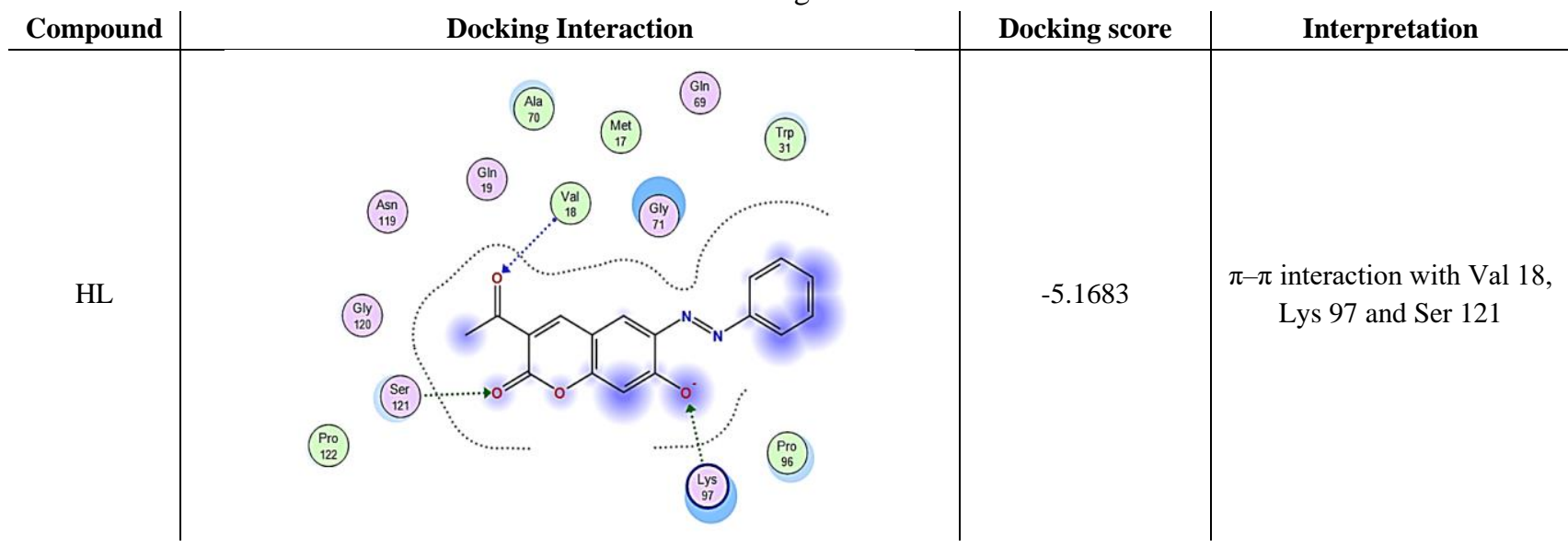




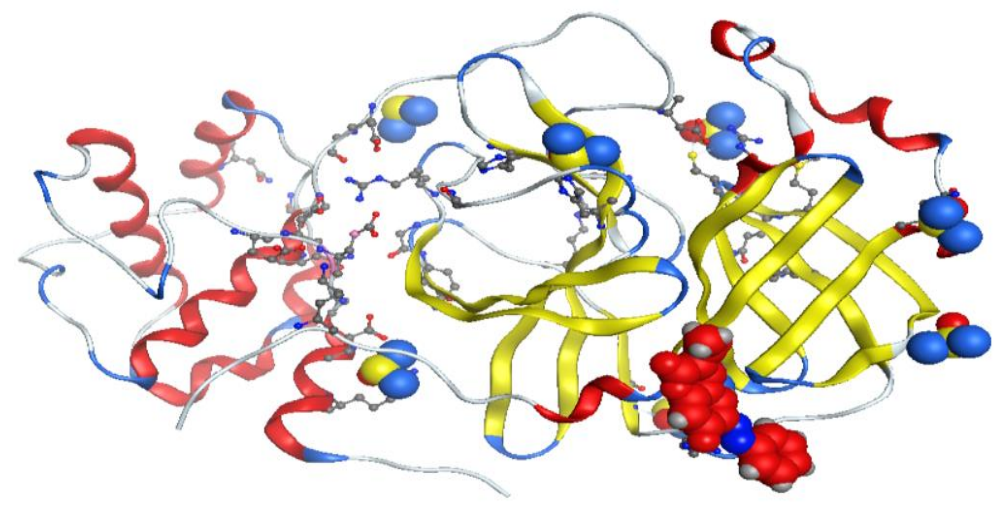

Figure 13. 3D interaction between HL and SARS-CoV-2 protease.

\subsection{Electronic absorption studies of DNA binding.}

Electronic absorption spectroscopy is an effective method to examine the binding mode and extent of metal complexes with DNA [34]. Generally, hypochromism and red-shift are associated with the intercalation of metal complexes to the DNA helix. The intercalative mode involves a strong stacking interaction between the aromatic chromophore of the complexes and the base pairs of DNA [34]. The interaction of HL and its complexes with CT-DNA has been studied with UV spectroscopy to investigate the possible binding modes to CT-DNA and to calculate the binding constants $\left(K_{\mathrm{b}}\right)$ to CT-DNA. Absorption titration experiments were performed with fixed concentrations of the ligand (HL) and its $\mathrm{Cu}$ (II), Ni(II), $\mathrm{Zn}$ (II) and $\mathrm{Mn}$ (II) complexes $(40 \mu \mathrm{M})$ while gradually increasing the concentration of DNA $(10 \mathrm{mM})$ at $25^{\circ} \mathrm{C}$. While measuring the absorption spectra, an equal amount of DNA was added to both the compound solution and the reference solution to eliminate the absorbance of DNA itself. We have determined the intrinsic binding constant to CT-DNA by monitoring the absorption intensity of the band at $338 \mathrm{~nm}$ for the ligand (HL), and 322, 415, 405 and $388 \mathrm{~nm}$ for metal complexes (1-4), respectively. The absorption spectra of its ligand and its metal complexes with increasing concentration of CT-DNA in the range 300-700 nm are shown in Fig. 14.

Upon the addition of an increasing amount of CT-DNA, a significant "hyperchromic" effect was observed accompanied by a moderate red-shift of 2-3 nm, indicative of stabilization of the DNA helix. These spectral characteristics suggest that the ligand and its complexes bind either to the external contact (electrostatic binding) or to the major and minor grooves of DNA. Moreover, this "hyperchromic effect" can be explained based on two phenomena. Firstly, the large surface area of the ligand, as well as the presence of planar aromatic chromophore, facilitates a strong binding interaction of the ligand with CT-DNA thereby, providing ample opportunity for the complex to bind with the CT-DNA via partial insertion of the aromatic moiety in between the stacking base pair. This groove binding results in structural reorganization of CT-DNA, which entails partial unwinding or damage of the double helix at the exterior phosphate backbone leading to the formation of a cavity to accommodate the complex. The intrinsic binding constants $\left(K_{b}\right)$ of all the ligands (HL) and its metal complexes (1-4) with CT-DNA were determined (Eq. 1) [18].

The $K_{b}$ value obtained from the absorption spectral technique for ligand (HL) was calculated (Table 9). The binding constant of the complexes (1-4) is comparatively higher than that of the ligand (HL), maybe due to the ligand considering that the phenolic - $\mathrm{OH}$ group may enhance their affinity towards DNA binding through the formation of hydrogen bonding. 
Table 9. DNA binding affinity.

\begin{tabular}{c|c} 
Compound & $\boldsymbol{K}_{\boldsymbol{b}} \mathbf{x}\left(\mathbf{1 0}^{\mathbf{5}} \mathbf{M}^{\mathbf{- 1}}\right)$ \\
\hline $\mathrm{HL}$ & 1.62 \\
\hline 1 & 2.89 \\
\hline 2 & 4 \\
\hline 3 & 5.92 \\
\hline 4 & 8.31
\end{tabular}
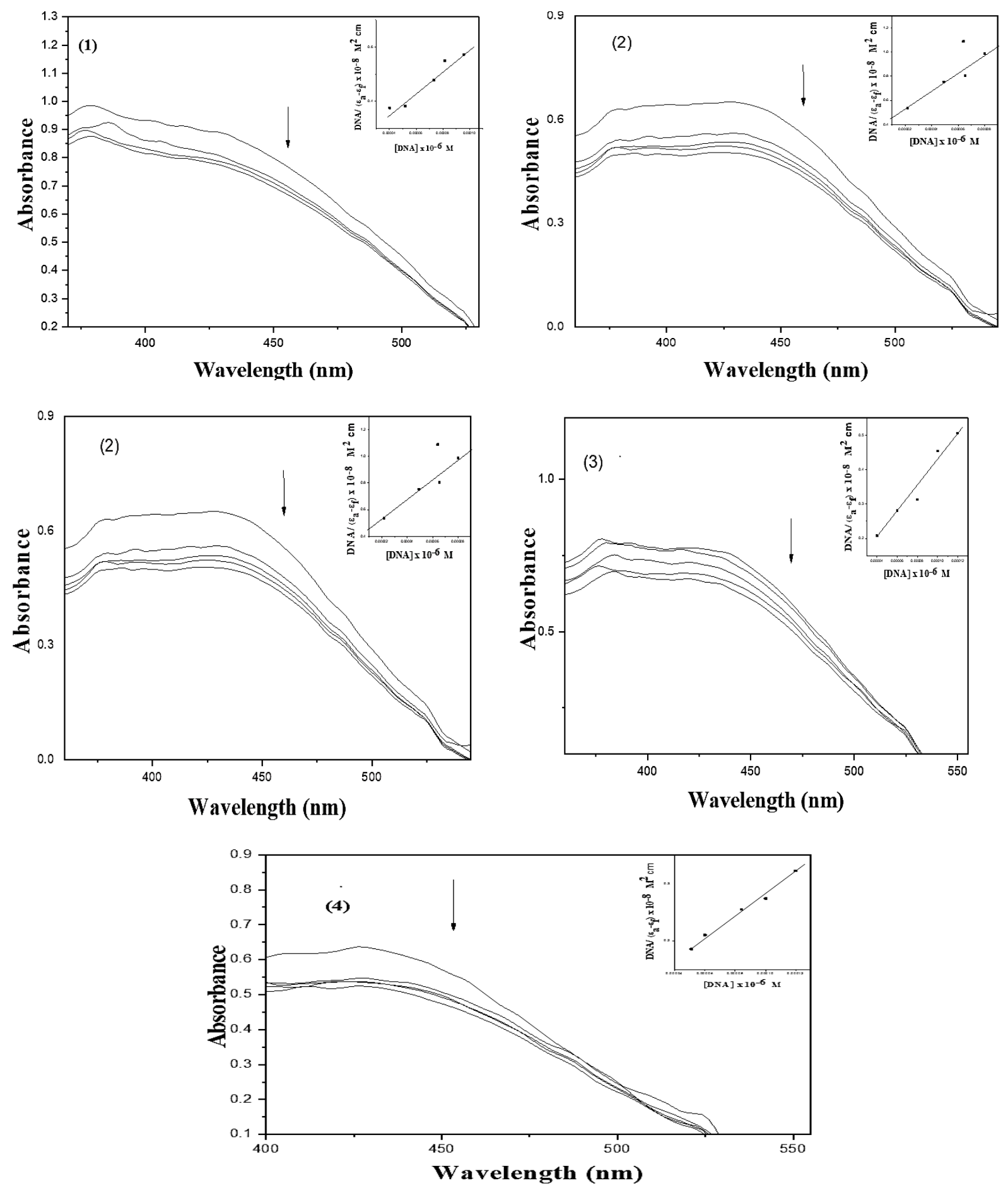

Figure 14. Absorption spectra of ligand (HL) and its metal complexes (1-4) in buffer $\mathrm{pH} 7.2$ at $25^{\circ} \mathrm{C}$ in the presence of an increasing amount of CT-DNA. Arrows indicate the changes in absorbance upon increasing the CT-DNA concentration. Inset: plot of [DNA] $/\left(\varepsilon_{\mathrm{a}}-\varepsilon_{\mathrm{f}}\right) \times 10^{-8} \mathrm{M}^{2} \mathrm{~cm} v s$. [DNA] $\times 10^{-6} \mathrm{M}$ for titration of DNA with the ligand (HL) and its complexes (1-4). 
3.10. Cytotoxicity Activity.

All the Synthesized Acetyl-6-(phenyl azo)-7-hydroxy coumarin (HL) and its metal complexes were evaluated for their cytotoxicity against human breast cancer (MCF-7) by MTT assay. Inhibitory activity against breast carcinoma cells (MCF-7 cell line) was tested using different samples' concentrations $(0.00,0.10,1.00,10.00,100.00$, and $1000 \mu \mathrm{g} / \mathrm{mL})$ and cell viability was measured at $540 \mathrm{~nm}$ using a microplate reader. The $50 \%$ inhibitory concentration (IC50) of the MCF-7 cell line was calculated from Figure 15.

The 50\% inhibitory concentration (IC50) of the (MCF-7) cell line was calculated from Tables 10 and 11 . The results of 50\% inhibitory concentration ( $\mathrm{IC}_{50}$ ) of test metal complexes showed a different variable activity compared to the ligand as shown in Table 16. As shown in Table 13, $\left[\mathrm{Cu}(\mathrm{L}) \mathrm{Cl}\left(\mathrm{OH}_{2}\right)\right] 2 \mathrm{H}_{2} \mathrm{O}, \quad\left[\mathrm{Ni}(\mathrm{L}) \mathrm{Cl}\left(\mathrm{OH}_{2}\right)_{3}\right], \quad\left[\mathrm{Zn}(\mathrm{L}) \mathrm{Cl}\left(\mathrm{OH}_{2}\right)\right] \mathrm{H}_{2} \mathrm{O} \quad$ and $\left[\mathrm{Mn}(\mathrm{L}) \mathrm{Cl}\left(\mathrm{OH}_{2}\right)_{3}\right] 2 \mathrm{H}_{2} \mathrm{O}$ were found to exhibit good cytotoxic activity against MCF-7 cells than the ligand $[18,34]$.

Table 10. Evaluation of cytotoxicity of ligand (HL) and its metal complexes (1-4) against MCF-7 cell line.

\begin{tabular}{c|c|c|c|c|c}
\multirow{2}{*}{ Conc. $\boldsymbol{\mu g} / \mathbf{m l}$} & \multicolumn{5}{|c}{ Cell Viability \% } \\
\cline { 2 - 6 } & HL & 1 & 2 & 3 & 4 \\
\hline HL & 0 & 100 & 100 & 100 & 100 \\
\hline 1 & 0.1 & 92.4 & 91.84 & 95.81 & 99.13 \\
\hline 2 & 1 & 98.6 & 90.06 & 93.61 & 96.41 \\
\hline 3 & 10 & 95.94 & 93.43 & 78.21 & 90.06 \\
\hline 4 & 100 & 53.43 & 4.49 & 52.7 & 47.78
\end{tabular}

Table 11. $\mathrm{IC}_{50}(\mu \mathrm{g} / \mathrm{ml})$ values of tested metal complexes and ligand against MCF-7 Cell line.

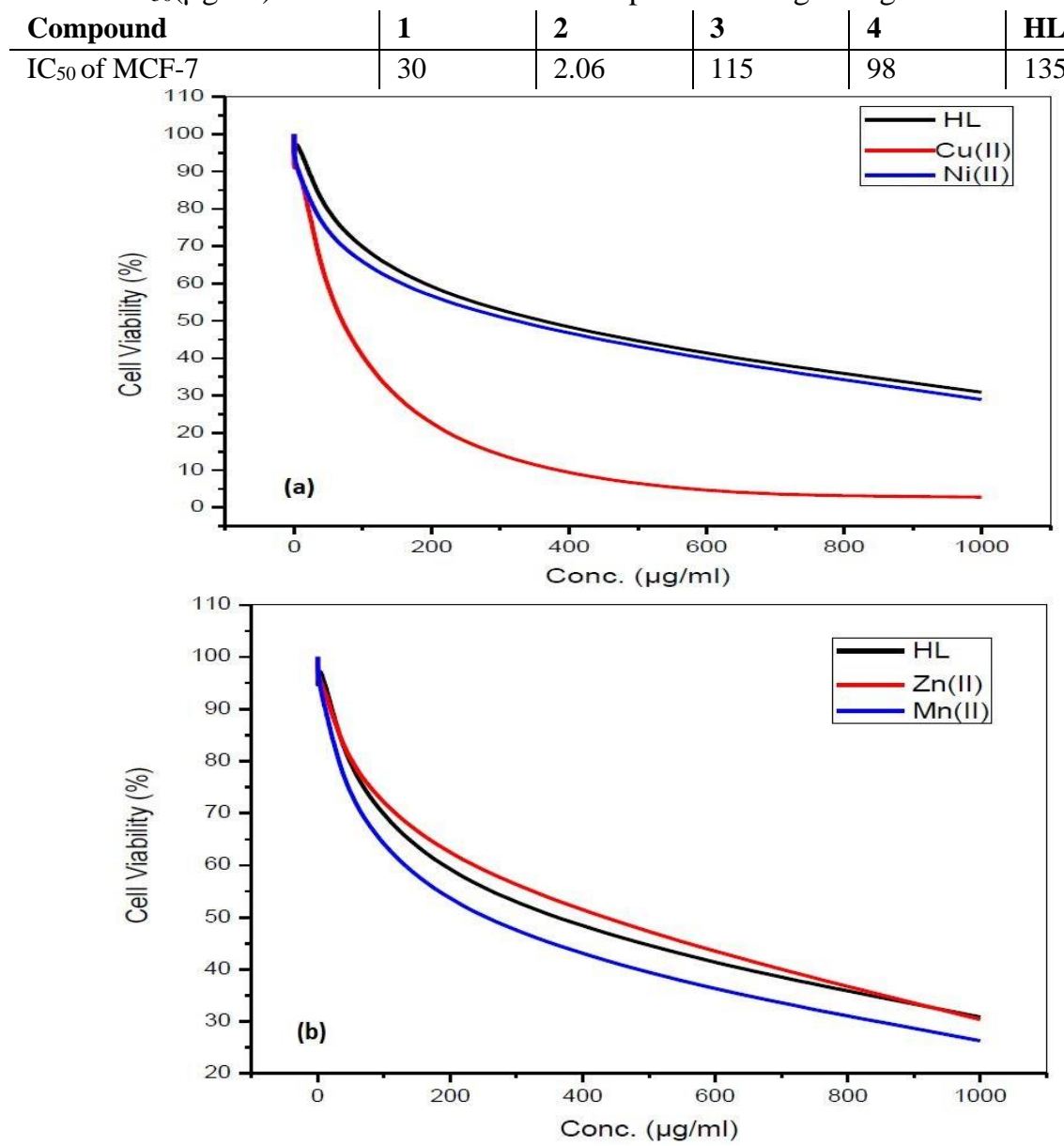

Figure 15. (a) Validity of the HL ligand and its $\mathrm{Cu}$ (II) \& Ni (II)complexes against MCF-7 cell line; (b) Validity of the HL ligand and its Zn (II) \& Mn(II) complexes against MCF-7 cell line. 
4. Conclusions

The structure of the ligand (HL) and its complexes were confirmed by elemental analyses, IR, ${ }^{1} \mathrm{H}$ NMR, molar conductance, and thermal analysis data. Therefore, from the IR spectrum, it is concluded that HL binds to the metal as a monobasic bidentate ligand by coordinating via the nitrogen atom of the azo group $(-\mathrm{N}=\mathrm{N}-)$ and the oxygen atom of the deprotonated phenolic $\mathrm{OH}$ group. The optimized bond lengths, bond angles, and calculated quantum chemical parameters for the ligand (HL) were investigated. The thermogravimetric analysis of the compounds shows that the values of activation energies of decomposition (Ea) are $16.2 \mathrm{~mol}^{-1}$ for the ligand and 47.9, 27.9, 38.7, and $24.5 \mathrm{~kJ} \mathrm{~mol}^{-1}$ for the complexes $\mathrm{Cu}$ (II), $\mathrm{Ni}(\mathrm{II}), \mathrm{Zn}(\mathrm{II})$, and $\mathrm{Mn}(\mathrm{II})$, respectively. The calf thymus DNA binding activity of the ligand (HL) and its metal complexes was studied by absorption spectra. The ligand considering that the phenolic - $\mathrm{OH}$ group may enhance their affinity towards DNA binding through the formation of hydrogen bonding. Molecular docking and binding energy calculations of azo dye with the receptor of breast cancer $3 \mathrm{hb5}$-oxidoreductase and prostate cancer mutant $2 \mathrm{q} 7 \mathrm{k}-$ Hormone indicated that the presence of the azo coumarin is an efficient inhibitor of breast cancer 3hb5-oxidoreductase and prostate cancer mutant $2 \mathrm{q} 7 \mathrm{k}-$ Hormone. Also, the measurement of the binding energy between the azo dye ligand with a receptor of COVID-19 virus 5epw and SARS virus mutant 5wrg approved that the azo coumarin is an efficient inhibitor for both COVID-19 and SARS viruses. The ligand (HL) and its metal complexes displayed good activity on MCF-7 (breast cancer) cells.

\section{Funding}

This research received no external funding.

\section{Acknowledgments}

This research has no acknowledgments.

\section{Conflicts of Interest}

The authors declare that they have no known competing financial interests or personal relationships that could have influenced the work reported in this paper.

\section{References}

1. Bogoch, I.I.; Watts, A.; Thomas-Bachli, A.; Huber, C.; Kraemer, M.U.; Khan, K. Pneumonia of unknown aetiology in Wuhan, China: potential for international spread via commercial air travel. Journal of travel medicine 2020, 27, taaa008, https://doi.org/10.1093/jtm/taaa008.

2. El-Bindary, A.A.; Toson, E.A.; Shoueir, K.R.; Aljohani, H.A.; Abo-Ser, M.M. Metal-organic frameworks as efficient materials for drug delivery: Synthesis, characterization, antioxidant, anticancer, antibacterial and molecular docking investigation. Appl. Organomet. Chem. 2020, 34, e5905, https://doi.org/10.1002/aoc.5905.

3. El-Hoshoudy, A. Investigating the potential antiviral activity drugs against SARS-CoV-2 by molecular docking simulation. J. Mol. Liq. 2020, 318, 113968, https://doi.org/10.1016/j.molliq.2020.113968.

4. Gautret, P.; Lagier, J.-C.; Parola, P.; Meddeb, L.; Mailhe, M.; Doudier, B.; Courjon, J.; Giordanengo, V.; Vieira, V.E.; Dupont, H.T. Hydroxychloroquine and azithromycin as a treatment of COVID-19: results of an open-label non-randomized clinical trial. Int J Antimicrob Agents 2020, 105949, https://doi.org/10.1016/j.ijantimicag.2020.105949.

5. Huang, C.; Wang, Y.; Li, X.; Ren, L.; Zhao, J.; Hu, Y.; Zhang, L.; Fan, G.; Xu, J.; Gu, X. Clinical features of patients infected with 2019 novel coronavirus in Wuhan, China. The Lancet 2020, 395, 497-506, https://doi.org/10.1016/S0140-6736(20)30183-5. 
6. Hui, D.S.; Azhar, E.I.; Madani, T.A.; Ntoumi, F.; Kock, R.; Dar, O.; Ippolito, G.; Mchugh, T.D.; Memish, Z.A.; Drosten, C. The continuing 2019-nCoV epidemic threat of novel coronaviruses to global health-The latest 2019 novel coronavirus outbreak in Wuhan, China. International Journal of Infectious Diseases 2020, 91, 264-266, https://doi.org/10.1016/j.ijid.2020.01.009.

7. Lai, C.-C.; Shih, T.-P.; Ko, W.-C.; Tang, H.-J.; Hsueh, P.-R. Severe acute respiratory syndrome coronavirus 2 (SARS-CoV-2) and corona virus disease-2019 (COVID-19): the epidemic and the challenges. International journal of antimicrobial agents 2020, 105924, https://doi.org/10.1016/j.ijantimicag.2020.105924.

8. Jin, Z.; Du, X.; Xu, Y.; Deng, Y.; Liu, M.; Zhao, Y.; Zhang, B.; Li, X.; Zhang, L.; Peng, C.; Duan, Y.; Yu, J.; Wang, L.; Yang, K.; Liu, F.; Jiang, R.; Yang, X.; You, T.; Liu, X.; Yang, X.; Bai, F.; Liu, H.; Liu, X.; Guddat, L.W.; Xu, W.; Xiao, G.; Qin, C.; Shi, Z.; Jiang, H.; Rao, Z.; Yang, H. Structure of Mpro from SARSCoV-2 and discovery of its inhibitors. Nature 2020, 582, 289-293, https://doi.org/10.1038/s41586-020-2223$\mathrm{y}$.

9. Piccoli, L.; Park, Y.-J.; Tortorici, M.A.; Czudnochowski, N.; Walls, A.C.; Beltramello, M.; Silacci-Fregni, C.; Pinto, D.; Rosen, L.E.; Bowen, J.E.J.C. Mapping neutralizing and immunodominant sites on the SARSCoV-2 spike receptor-binding domain by structure-guided high-resolution serology. Cell 2020, 183, 10241042. e1021, https://doi.org/10.1016/j.cell.2020.09.037.

10. Robson, B. Computers and viral diseases. Preliminary bioinformatics studies on the design of a synthetic vaccine and a preventative peptidomimetic antagonist against the SARS-CoV-2 (2019-nCoV, COVID-19) coronavirus. Comput. Biol. Med. 2020, 119, 103670, https://doi.org/10.1016/j.compbiomed.2020.103670.

11. Rothan, H.A.; Byrareddy, S.N. The potential threat of multisystem inflammatory syndrome in children during the COVID-19 pandemic. Pediatr. Allergy Immunol. 2021, 32, 17-22, https://doi.org/10.1111/pai.13361.

12. Sahraei, Z.; Shabani, M.; Shokouhi, S.; Saffaei, A. Aminoquinolines against coronavirus disease 2019 (COVID-19): chloroquine or hydroxychloroquine. Int $J$ Antimicrob Agents 2020, 105945, https://doi.org/10.1016/j.ijantimicag.2020.105945.

13. Sahyon, H.A.; El-Bindary, A.A.; Shoair, A.F.; Abdellatif, A.A. Synthesis and characterization of ruthenium (III) complex containing 2-aminomethyl benzimidazole, and its anticancer activity of in vitro and in vivo models. J. Mol. Liq. 2018, 255, 122-134, https://doi.org/10.1016/j.molliq.2018.01.140.

14. Tobaiqy, M.; Qashqary, M.; Al-Dahery, S.; Mujallad, A.; Hershan, A.A.; Kamal, M.A.; Helmi, N. Therapeutic management of patients with COVID-19: a systematic review. Infection Prevention in Practice 2020, 2, 100061, https://doi.org/10.1016/j.infpip.2020.100061.

15. Wu, C.; Liu, Y.; Yang, Y.; Zhang, P.; Zhong, W.; Wang, Y.; Wang, Q.; Xu, Y.; Li, M.; Li, X.; Zheng, M.; Chen, L.; Li, H. Analysis of therapeutic targets for SARS-CoV-2 and discovery of potential drugs by computational methods. Acta Pharmaceutica Sinica B 2020, 10, 766-788, https://doi.org/10.1016/j.apsb.2020.02.008.

16. Xia, S.; Liu, M.; Wang, C.; Xu, W.; Lan, Q.; Feng, S.; Qi, F.; Bao, L.; Du, L.; Liu, S.; Qin, C.; Sun, F.; Shi, Z.; Zhu, Y.; Jiang, S.; Lu, L. Inhibition of SARS-CoV-2 (previously 2019-nCoV) infection by a highly potent pan-coronavirus fusion inhibitor targeting its spike protein that harbors a high capacity to mediate membrane fusion. Cell Res. 2020, 30, 343-355, https://doi.org/10.1038/s41422-020-0305-X.

17. Zhu, N.; Zhang, D.; Wang, W.; Li, X.; Yang, B.; Song, J.; Zhao, X.; Huang, B.; Shi, W.; Lu, R.; Niu, P.; Zhan, F.; Ma, X.; Wang, D.; Xu, W.; Wu, G.; Gao, G.F.; Tan, W. A Novel Coronavirus from Patients with Pneumonia in China, 2019. New Engl. J. Med. 2020, 382, 727-733, https://doi.org/10.1056/NEJMoa2001017.

18. El-Bindary, A.A.; Hassan, N.; El-Afify, M.A. Synthesis and structural characterization of some divalent metal complexes: DNA binding and antitumor activity. J. Mol. Liq. 2017, 242, 213-228, https://doi.org/10.1016/j.molliq.2017.07.009.

19. Hassan, N.; Shahat, A.; El-Didamony, A.; El-Desouky, M.; El-Bindary, A. Synthesis and characterization of $\mathrm{ZnO}$ nanoparticles via zeolitic imidazolate framework-8 and its application for removal of dyes. Journal of molecular structure 2020, 1210, 128029, doi:https://doi.org/10.1016/j.molstruc.2020.128029.

20. El-Ghamaz, N.A.; Diab, M.A.; El-Bindary, A.A.; El-Sonbati, A.Z.; Seyam, H.A. Geometrical structure and optical properties of antipyrine Schiff base derivatives. Mater. Sci. Semicond. Process. 2014, 27, 521-531, https://doi.org/10.1016/j.mssp.2014.07.022.

21. Kiwaan, H.A.; Atwee, T.M.; Azab, E.A.; El-Bindary, A.A. Photocatalytic degradation of organic dyes in the presence of nanostructured titanium dioxide. J. Mol. Struct. 2020, 1200, 127115. https://doi.org/10.1016/j.molstruc.2019.127115.

22. El-Sonbati, A.Z.; Shoair, A.F.; El-Bindary, A.A.; Diab, M.A.; Mohamed, A.S. Synthesis, characterization, DNA binding and catalytic activities of Ru(III) complexes. J. Mol. Liq. 2015, 209, 635-647, https://doi.org/10.1016/j.molliq.2015.06.019. 
23. El-Bindary, A.A.; Anwar, Z.; El-Shafaie, T. Effect of silicon dioxide nanoparticles on the assessment of quercetin flavonoid using Rhodamine B Isothiocyanate dye. J. Mol. Liq. 2020, 114607. https://doi.org/10.1016/j.molliq.2020.114607.

24. Shoair, A.F.; El-Bindary, A.A. Synthesis, spectral and catalytic dehydrogenation studies of ruthenium complexes containing NO bidentate ligands. Spectrochim. Acta A 2014, 131, 490-496, https://doi.org/10.1016/j.saa.2014.04.132.

25. Rani, S.; Gahlot, K.; Kumar, A. Experimental evidences of antidiabetic activity of aqueous extract of Cressa cretica L. on streptozotocin induced diabetes in rats. Letters in Applied NanoBioScience 2020, 9, 774-778, https://doi.org/10.33263/LIANBS91.774778.

26. Nayak, R.; Nanda, B. A review on formulation, design of nanostructured material through oil-in-water microemulsion. Letters in Applied NanoBioScience 2020, 9, 945-951, https://doi.org/10.33263/LIANBS92.945951.

27. Horst, D.J.; de Andrade Junior, P.P. Evaluating the Electrical Conductivity and Resistivity of Carbon Nanostructures Embedded in the PLA Matrix. Letters in Applied NanoBioScience 2020, 9, 1141-1146, https://doi.org/10.33263/LIANBS93.11411146.

28. Daravath, S.; Kumar, M.P.; Rambabu, A.; Vamsikrishna, N.; Ganji, N.; Shivaraj. Design, synthesis, spectral characterization, DNA interaction and biological activity studies of copper(II), cobalt(II) and nickel(II) complexes of 6-amino benzothiazole derivatives. J. Mol. Struct. 2017, 1144, 147-158, https://doi.org/10.1016/j.molstruc.2017.05.022.

29. Hassan, N.; Shahat, A.; El-Didamony, A.; El-Desouky, M.; El-Bindary, A. Mesoporous iron oxide nano spheres for capturing organic dyes from water sources. J Journal of Molecular Structure 2020, 1217, 128361, doi:https://doi.org/10.1016/j.molstruc.2020.128361.

30. Mohanraj, M.; Ayyannan, G.; Raja, G.; Jayabalakrishnan, C. Synthesis, characterization and in vitro biological assays of copper(II) and nickel(II) complexes with furan--2--carboxylic acid hydrazide. Appl. Organomet. Chem. 2017, 31, e3582, https://doi.org/10.1002/aoc.3582.

31. Pahonţu, E.; Julea, F.; Chumakov, Y.; Petrenco, P.; Roşu, T.; Gulea, A. Synthesis, characterization, crystal structure and antiproliferative activity studies of $\mathrm{Cu}(\mathrm{II}), \mathrm{Ni}$ (II) and $\mathrm{Co}(\mathrm{II})$ complexes with 4-benzoyl-5pyrazolones derived compounds. J. Organomet. Chem. 2017, 836-837, 44-55, https://doi.org/10.1016/j.jorganchem.2017.01.018.

32. Justin Dhanaraj, C.; Johnson, J. DNA interaction, antioxidant and in vitro cytotoxic activities of some mononuclear metal(II) complexes of a bishydrazone ligand. Materials Science and Engineering: C 2017, 78, 1006-1015, https://doi.org/10.1016/j.msec.2017.04.152.

33. de Araújo, E.L.; Barbosa, H.F.G.; Dockal, E.R.; Cavalheiro, É.T.G. Synthesis, characterization and biological activity of $\mathrm{Cu}(\mathrm{II}), \mathrm{Ni}(\mathrm{II})$ and $\mathrm{Zn}(\mathrm{II})$ complexes of biopolymeric Schiff bases of salicylaldehydes and chitosan. Int. J. Biol. Macromol. 2017, 95, 168-176, https://doi.org/10.1016/j.ijbiomac.2016.10.109.

34. Hassan, N.; El-Sonbati, A.; El-Desouky, M. Synthesis, characterization, molecular docking and DNA binding studies of $\mathrm{Cu}(\mathrm{II}), \mathrm{Ni}(\mathrm{II}), \mathrm{Zn}(\mathrm{II})$ and $\mathrm{Mn}(\mathrm{II})$ complexes. J. Mol. Liq. 2017, 242, 293-307, https://doi.org/10.1016/j.molliq.2017.07.019.

35. Abdel-Monem, Y.K.; Abou El-Enein, S.A.; El-Sheikh-Amer, M.M. Design of new metal complexes of 2-(3amino-4,6-dimethyl-1H-pyrazolo[3,4-b]pyridin-1-yl)aceto-hydrazide: Synthesis, characterization, modelling and antioxidant activity. J. Mol. Struct. 2017, 1127, 386-396, https://doi.org/10.1016/j.molstruc.2016.07.110.

36. Tkach, V.V.; Kushnir, M.V.; de Oliveira, S.C.; Ivanushko, Y.G.; Velyka, A.V.; Molodianu, A.F.; Yagodynets, P.I.; Kormosh, Z.O.; Reis, L.; Luganska, O. Electrochemical Determination of Sudan Dyes and Two Manner to Realize it: a Theoretical Investigation. Letters in Applied NanoBioScience 2020, 9, 14511458, https://doi.org/10.33263/LIANBS94.14511458.

37. Rao, D. A review on versatile applications of noval schiff bases and their metal complexes. Letters in Applied NanoBioScience 2019, 8, 675-681, https://doi.org/10.33263/LIANBS84.675681.

38. Punvichai, T.; Pioch, D. Co-valorization of agro-industry by-products: effect of citrus oil on the quality of soap derived from palm fatty acid distillate and spent bleaching clay. J Letters in Applied NanoBioScience 2019, 8, 571-575, https://doi.org/10.33263/LIANBS83.571575.

39. Coats, A.W.; Redfern, J.P. Kinetic Parameters from Thermogravimetric Data. Nature 1964, 201, 68-69, https://doi.org/10.1038/201068a0.

40. Horowitz, H.H.; Metzger, G. A New Analysis of Thermogravimetric Traces. Anal. Chem. 1963, 35, 14641468, https://doi.org/10.1021/ac60203a013.

41. Hassan, N.; Shahat, A.; El-Didamony, A.; El-Desouky, M.; El-Bindary, A. Equilibrium, Kinetic and Thermodynamic studies of adsorption of cationic dyes from aqueous solution using ZIF-8. J Moroccan 
Journal of Chemistry 2020, 8, 8-3 (2020) 2627-2637, doi: https://doi.org/10.48317/IMIST.PRSM/morjchem-v8i3.21127.

42. Chitrala, K.N.; Yang, X.; Busbee, B.; Singh, N.P.; Bonati, L.; Xing, Y.; Nagarkatti, P.; Nagarkatti, M. Computational prediction and in vitro validation of VEGFR1 as a novel protein target for 2,3,7,8tetrachlorodibenzo-p-dioxin. Sci. Rep. 2019, 9, 6810, https://doi.org/10.1038/s41598-019-43232-4.

43. Shoair, A.F.; El-Bindary, A.A.; El-Ghamaz, N.A.; Rezk, G.N. Synthesis, characterization, DNA binding and antitumor activities of $\mathrm{Cu}(\mathrm{II})$ complexes, J. Mol. Liq. 2018, 269, 619-638, https://doi.org/10.1016/j.molliq.2018.08.075.

44. Macchiagodena, M.; Pagliai, M.; Procacci, P. Identification of potential binders of the main protease 3CLpro of the COVID-19 via structure-based ligand design and molecular modeling. Chem. Phys. Lett. 2020, 750, 137489, https://doi.org/10.1016/j.cplett.2020.137489.

45. Mohamed, G.; Hassan, N.; Shahat, A.; El-Didamony, A.; Ashraf, A. Synthesis and Characterization of Porous Magnetite Nanosphere Iron Oxide as a Novel Adsorbent of Anionic Dyes Removal from Aqueous Solution. Biointerface Resarch in Applied Chemistry 2021, 11, 13377-13401, doi: https://doi.org/10.33263/BRIAC115.1337713401. 